\title{
Paleoecology of Llandovery conodonts, Anticosti Island, Québec
}

\author{
Shunxin Zhang, Christopher R. Barnes* \\ School of Earth and Ocean Sciences, University of Victoria, P.O. Box 3055, Victoria, BC, Canada V8W $3 P 6$
}

Received 6 December 2000; received in revised form 24 July 2001; accepted 11 October 2001

\begin{abstract}
Anticosti Island, Québec, has perhaps the most fossiliferous and complete Llandovery (Early Silurian) sequence in the world. The undeformed limestones are well exposed and yield extremely well preserved conodonts whose taxonomy and biostratigraphy has been studied in detail. In addition to documenting the general temporal and spatial distribution of Llandovery conodonts, a set of 107 conodont samples was taken from four cliff sections in the lower and upper Becscie, lower Gun River, and upper Jupiter formations. These samples were used to examine the relationship of conodont elements and communities with microfacies, and explore their change through time. Over 9300 conodonts elements were identified and subjected to cluster analysis. The sections comprise mainly the background sedimentation of lime mudstones, deposited in 30-100 $\mathrm{m}$ of water on a gentle ramp. These mudstones are variably affected by interbeds or channel fill deposits interpreted as tempestites. A pattern of evolving conodont communities is documented for the lime mudstone facies through time. Different communities are found in the tempestite deposits that do not suggest a reworking of the mudstones, but rather the importation of deeper offshore faunas during periods of storm surge onto the ramp. The tempestites contain the highest species diversity and show no evidence of reduced diversity through post-mortem selective sorting by the storms. (C) 2002 Elsevier Science B.V. All rights reserved.
\end{abstract}

Keywords: Anticosti Island; cluster analysis; conodonts; Llandovery; paleoecology

\section{Introduction}

The paleoecology of conodonts is moderately well known from a number of earlier studies and has been summarized by Barnes (1976), Sweet (1988) and Pohler and Barnes (1990). Most of the current understanding, however, has come from

\footnotetext{
* Corresponding author. Tel.: +1-250-721-8847; Fax: +1-250-721-6200.

E-mail addresses: zhangs@uvic.ca (S. Zhang), crbarnes@uvic.ca (C.R. Barnes).
}

the analysis of sample data that was primarily taken to resolve biostratigraphic issues. Only rarely have sample strategies targeted paleoecology as the principal objective of the study. In most cases, studies have tended to address either problems at the higher hierarchical scale of faunal realms or provinces (e.g. Barnes et al., 1973; Sweet and Bergström, 1974) or at the lower level of conodont communities or biofacies (e.g. Barnes and Fåhræus, 1975; Sweet and Bergström, 1984). Some early work by Varker (1968) attempted to examine the variation in conodont element distri- 


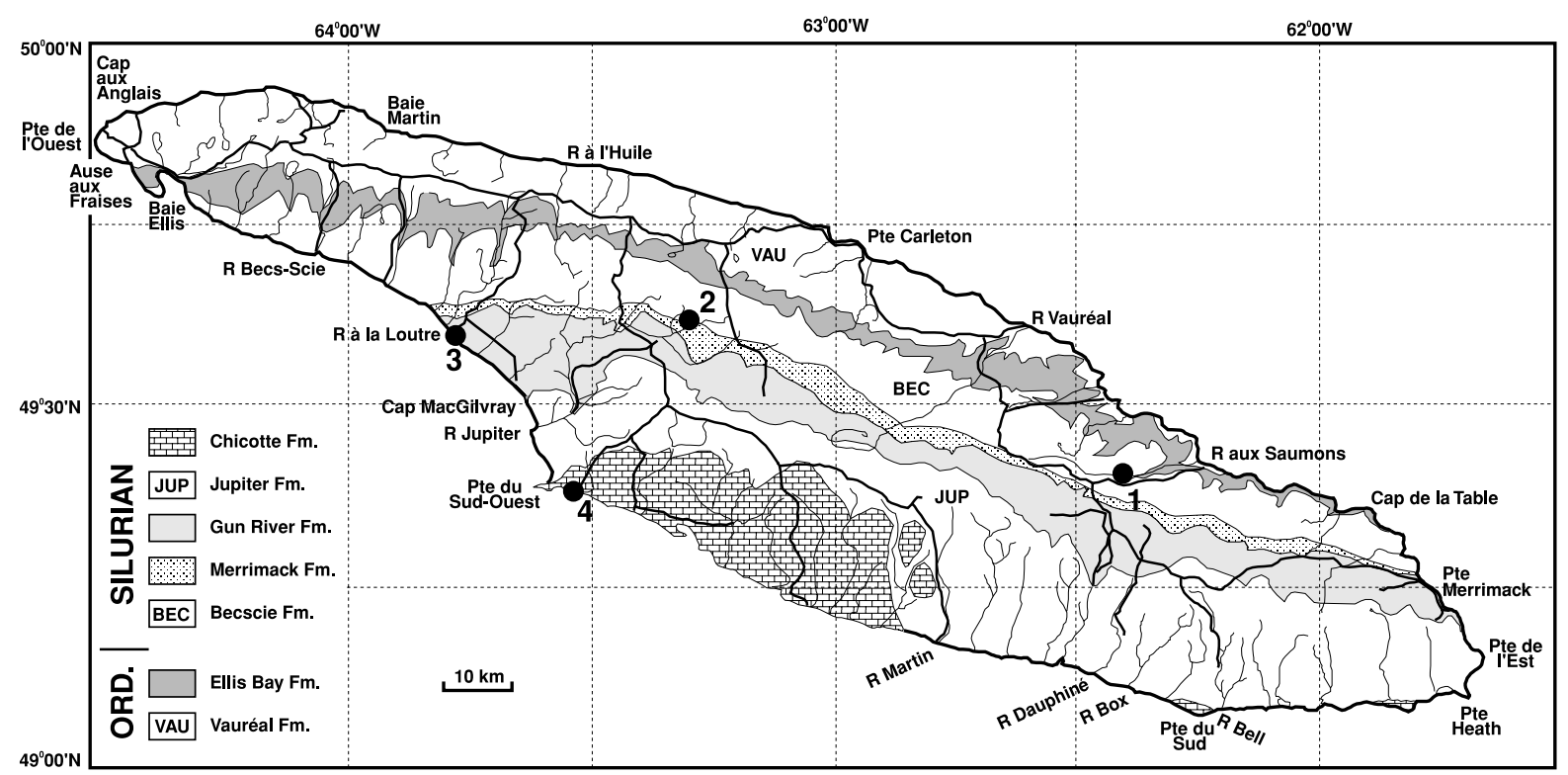

Fig. 1. Map of Anticosti Island showing distribution of Vauréal, Ellis Bay, Becscie, Merrimack, Gun River, Jupiter and Chicotte formations and the localities of the four sections used in this paleoecological study (modified from Jin and Copper, 1999).

bution through bed-by-bed sampling on a fine stratigraphic scale. A more recent study by McGoff (1991) examined the hydrodynamic properties of the phosphatic conodont elements under different flow regimes using flume experiments. The present study was designed to focus on the changing pattern of fine scale distribution of conodont elements using four sampling intervals through the Llandovery (Lower Silurian). The four sections selected are from the superb river and coastal cliff sections that outcrop on Anticosti Island, Québec (Fig. 1). The strata are subhorizontal, thermally unaltered to any significant degree, and yield exceptionally well preserved conodonts. The conodont faunas from the entire Anticosti Island succession (Upper OrdovicianLower Silurian) have now been studied in great detail in terms of their taxonomy and biostratigraphy. It is possible, therefore, to build on these studies to examine aspects of the conodont paleoecology.

It has been well documented that before the Ordovician-Silurian mass extinction, conodonts during the Middle and Late Ordovician were well differentiated into different realms and provinces and different biofacies (Sweet and Berg- ström, 1974). The extinction, related to the continental glaciation in North Africa, affected conodonts severely with only a few, primarily coniform, taxa crossing the boundary (Barnes and Bergström, 1988; Sepkoski, 1995). However, after the mass extinction, taxonomic diversity at the generic level was reduced by about $50-60 \%$, and the pattern of conodont faunal realms and provinces is much subdued.

Two general ecological models have been used to explain the distribution of conodonts in Paleozoic and Triassic marine rocks. One favored a community distribution based on depth stratification (Seddon and Sweet, 1971), whereas the other argued for a nektobenthic mode of life with the community pattern strongly influenced by bottom substrate conditions but including some pelagic conodonts (Barnes and Fåhræus, 1975). A combination of these was advanced in a model by Druce (1973). Klapper and Barrick (1978) noted the difficulty of determining the true community structure from element distribution data. It is important that the environmental conditions need to be examined along with the element distribution before a conodont ecological model can be constructed or tested. 
With regard to Early Silurian conodonts, their broad biofacies distribution was demonstrated most widely during the 1970s and 1980s, through species distribution patterns and relative frequencies of particular taxa. The relatively simple models and patterns deduced from some particular studies include the following developments.

(1) The distribution of some pectiniform-ramiform multielement taxa in Britain is broadly comparable with that of the brachiopod-dominated benthic communities, which appear to have been principally controlled by water depth and substrate conditions. The distribution of other taxa correlates more closely with wave energy (Icriodella Rhodes, Distomodus Branson and Branson), whereas the coniform taxa show a clear pattern of increased relative abundance with depth (Aldridge, 1976).

(2) Variations in conodont distribution in the Hudson Bay Basin respond to periodic rapid vertical and lateral facies changes. The communities are arranged progressively along an onshore to offshore cline. Within the partially evaporitic sequence, most conodonts appear to have been stenohaline with few euryhaline exceptions (Le Fèvre et al., 1976).

(3) The relative abundance of conodonts from the Pterospathodus amorphognathoides Zone of the Welsh Basin (Aldridge and Mabillard, 1981) and the Distomodus kentuckyensis Zone of Norway (Idris, 1984) shows that some species were almost totally restricted to nearshore localities, whereas others preferred a more offshore environment. Distribution boundaries were rather blurred, perhaps reflecting gradational environmental parameters across a gently sloping carbonate platform.

(4) Initial study of the lowermost Silurian conodont communities of Anticosti Island showed differences at the specific rather than generic level. There was a change in relative abundance of certain taxa and prominent forms such as Ozarkodina Branson and Mehl and Oulodus Branson and Mehl were considered to indicate a shallow sublittoral environment (McCracken and Barnes, 1981).

(5) More global analysis recognized that in shallow environments genera with apparatuses of robust elements were commonly dominant; in contrast, quieter, more offshore facies are commonly characterized by abundance of delicate specimens (Aldridge and Jeppsson, 1984). This may be a response to phosphate or nutrient availability.

These studies were based on a sampling strategy designed for biostratigraphic purposes. However, it provides distributional data that reflect the change of conodont communities vertically. Rapid facies change, or the sampling of several, laterally equivalent sections, can yield information on the lateral distribution and variation in conodont communities. In some studies, the factor of community evolution through time has not been clarified, due to an inadequate sampling strategy.

It has been suggested that different habitats within the Llandovery shelf seas supported different associations of conodont species (Aldridge, 1976; Le Fèvre et al., 1976): the "members of such associations would be expected to occur together even after death, unless their remains were differentially transported by wave or current activity. Some post-mortem mixing of specimens from different life associations must have occurred, but careful examination of conodont occurrences in a large number of separate collections should permit at least the partial recognition of some the original associations" (Aldridge, 1976, p. 98). Large, detailed collections should be made both vertically and horizontally.

The Lower Silurian cliff exposures on Anticosti Island afford an excellent opportunity for such detailed sampling to determine how conodont communities were distributed in relation to different environments and microfacies, and also within selected time intervals through the Llandovery to test the impact of community evolution. Anticosti Island, located in the Gulf of St. Lawrence, is underlain by Upper Ordovician (late Richmondian and Gamachian/Hirnantian) and Lower Silurian (Llandovery) strata (Fig. 1). The strata are divided into the Vauréal, Ellis Bay, Becscie, Merrimack, Gun River, Jupiter and Chicotte formations. The whole sequence, totaling about 800 $1100 \mathrm{~m}$ in thickness, is represented by exposures 


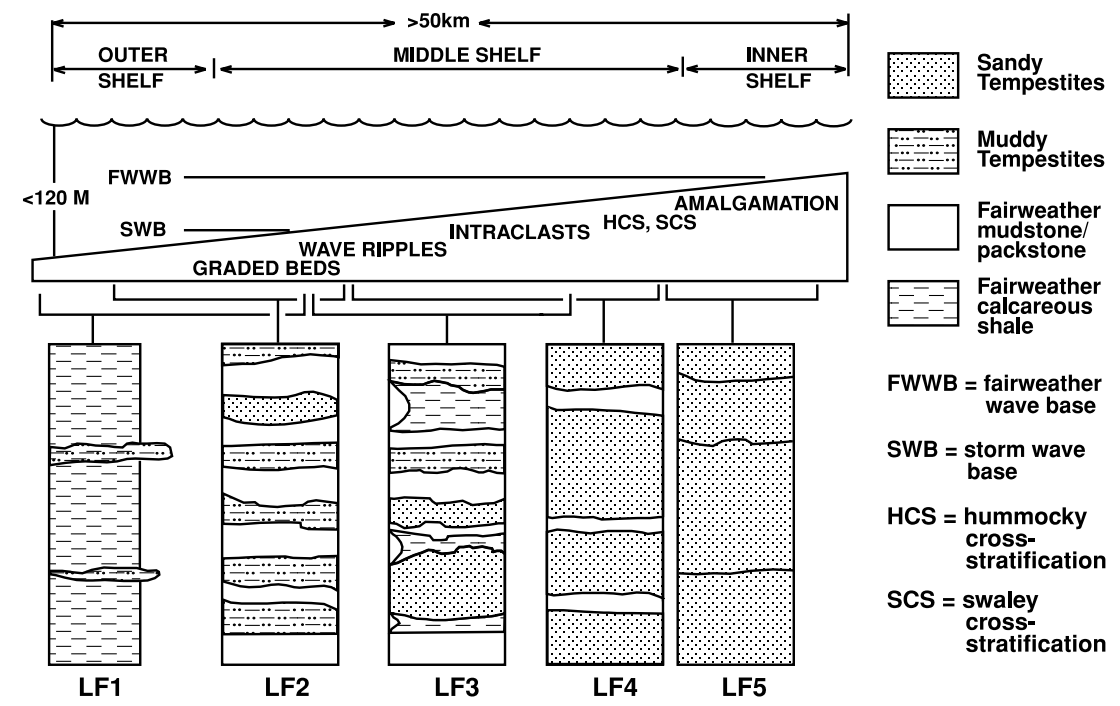

Fig. 2. Depositional profile of the Becscie and Merrimack formations showing lateral relationships between the five lithofacies types. Of particular note is the overlapping of the depositional environments of LF1, LF2, LF3 and LF4 (modified from Sami and Desrochers, 1992). FWWB = Fairweather-wave base; SWB = storm-wave base.

of richly fossiliferous limestone and minor shale and siliciclastics (Petryk, 1981a), dipping about two degrees to the south-west. During the Early Silurian, the Anticosti Basin was situated at a paleolatitude of $15-20^{\circ}$ south, on the northwest margin of the Iapetus Ocean (Ziegler et al., 1977, 1979; Scotese et al., 1985; Scotese, 1997). Most of the Upper Ordovician and Lower Silurian sediments were deposited in a shallow, storminfluenced, open-marine sublittoral environment. Barnes et al. (1981) and Lespérence (1981) give details of the stratigraphy and the paleontology for the sequence, respectively.

Detailed studies on the conodont faunas and conodont biostratigraphy of the entire Anticosti sequence have been undertaken by Nowlan and Barnes (1981), McCracken and Barnes (1981), Uyeno and Barnes (1983), Barnes (1988, 1989), and Zhang and Barnes (2000, 2002a). Lithostratigraphic and paleoenvironmental studies have been undertaken mainly since the 1970 s by Petryk (1979a,b, 1980, 1981a-c), Petryk and Bertrand (1981), Sami and Desrochers (1992), Copper and Long (1989, 1990, 1998), Jin and Copper (1999), and Dewing (1999).

\section{Materials and methods}

The conodont collections were made especially for this conodont paleoecological study and are not those used other studies noted above to document the taxonomy and biostratigraphy. Four cliff sections were measured, described and sampled for conodonts from four different locations (Fig. 1). These were selected to represent four intervals within the Llandovery, from (a) the lower part of Becscie Formation, below the main falls along the Rivière aux Saumons (McCracken and Barnes, 1981, fig. 10, section IIID) (Fig. 3), (b) the upper part of Becscie Formation, $1 \mathrm{~km}$ north of 24-Mile Lodge on the Rivière Jupiter (Bolton, 1972, fig. 11) (Fig. 6), (c) the lower part of Gun River Formation on the south coast, $2 \mathrm{~km}$ west of the mouth of Rivière à La Loutre (Bolton, 1972, fig. 12) (Fig. 9), and (d) from the upper part of Jupiter Formation at Jumpers on the south coast (Uyeno and Barnes, 1983, fig. 2) (Fig. 12). Each of the river or coastal outcrops comprises a vertical, well exposed cliff, the base of which was studied over a rectangular area approximately $15-20 \mathrm{~m}$ horizontally by $1.5 \mathrm{~m}$ 


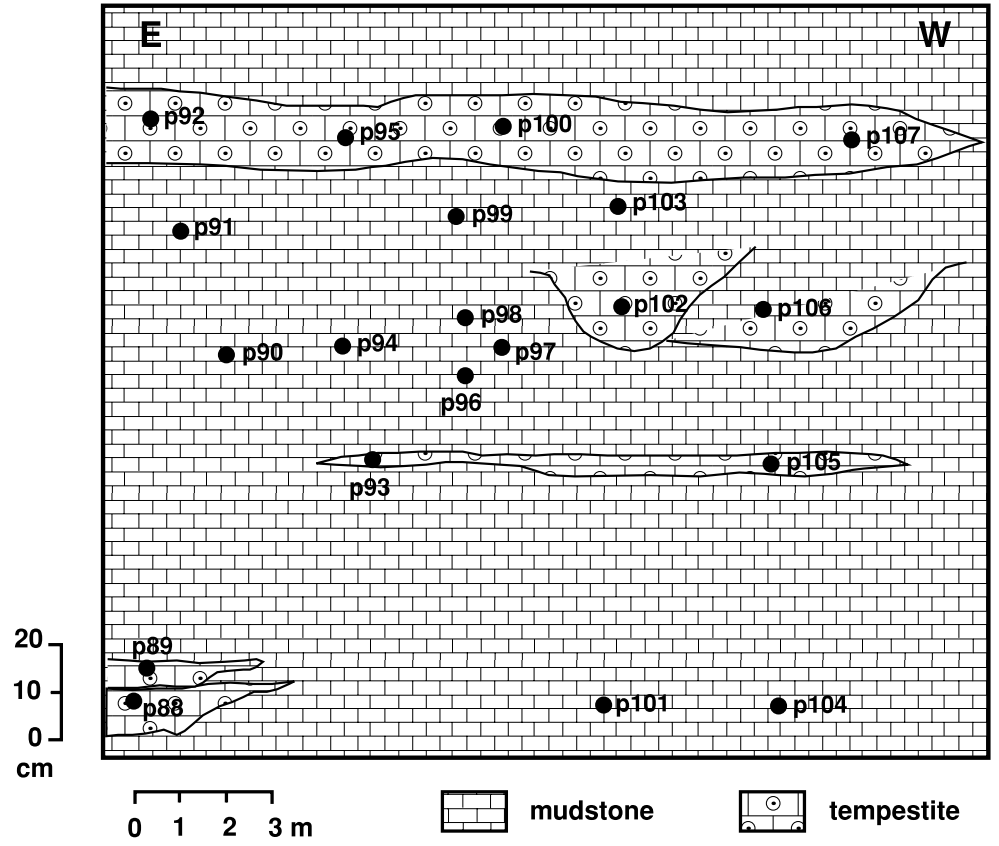

Fig. 3. Generalized sketch (view E-W) and sampling positions of interval I (earliest Rhuddanian) in lower member 1, Becscie Formation, at 9-Mile Pool of the Rivière aux Saumons, Anticosti Island, Québec.

vertically, with $20-30$ conodont samples collected. Thin sections were made of all samples to evaluate more completely the sedimentary environments represented. The total of 107 samples were collected from the four sections, and $1.5 \mathrm{~kg}$ of each was processed with only few grams residue undissolved in a few samples, producing a total of 9361 identifiable conodont specimens. These were identified as multielement taxa based on the earlier and current taxonomic studies reported above.

Community analysis employed cluster analysis of species element abundance data and was performed by SPSS version 6.1 for the Macintosh (SPSS, 1994). Interval data were chosen (species abundance data, i.e. the total number of specimens referable to a species in one $1.5 \mathrm{-kg}$ sample, are divided into six intervals, 1-4, 5-9, 10-24, 2549, 50-99 and $\geq 100$; see Figs. 5, 8, 11 and 14). Pearson's correlation coefficient was used as an index of similarity, and clusters were formed using the within-groups linkage method. Cluster analysis tends to divide an ecological gradient into dis- crete units and the gradational nature of many of the community groups is evident in the abundance data present with the Q- and R-type dendrograms (Figs. 5, 8, 11 and 14). When samples in Q-type clustering order and taxa in R-type clustering order are put together and the absolute abundance of taxa are expressed as a graded series of dots, the different communities can be recognized by the taxa with higher absolute abundance and/or the taxa being the characteristic species as shaded in Figs. 5, 8, 11 and 14. This approach was described and used successfully by Westrop and Cuggy (1999) who studied Cambrian trilobite paleoecology. It is important to emphasize that complex conodont biofacies were not likely to have been discrete entities, but cluster analysis can define associations of taxa with comparable habitat preferences, and can relate the broad patterns of conodont communities to associated lithofacies. Simple chi-square tests are formed to test for interaction between lithofacies and presence or absence of certain species. Some species show a close relationship with certain lithofacies, others do not. 


\section{Cluster analysis and conodont communities}

\subsection{Interval I-Earliest Rhuddanian conodont communities}

The Ordovician-Silurian boundary on Anticosti Island is one of the few fossiliferous, continuous sections at this level in the world (Barnes, 1988) and is followed by an exceptionally fossiliferous and complete Llandovery sequence (Barnes, 1989). The lowest unit of the Rhuddanian Stage (Llandovery Series) is the Becscie Formation (Copper and Long, 1989; Zhang and Barnes, 2002a). Herein, Petryk's (1981a) lithostratigraphic division is followed, i.e. placing most of Bolton's member 6 of the Upper Ordovician Ellis Bay Formation (Bolton, 1972) into the Lower Silurian Becscie Formation.

Bolton (1972) first subdivided the Becscie Formation into two transitional, lower and upper members; Petryk (1981a) informally subdivided this formation into members $1-4$, and Copper and Long (1989) placed Petryk's upper two members in a new formation, the Merrimack Formation while renaming members 1 and 2 as the Fox Point Member and Chabot Member, respectively. Sami and Desrochers (1992) followed Copper and Longs' stratigraphical division and divided the Becscie Formation into two members, which are similar to Petryk's (1981a) members 1 and 2, but reassessed the boundary between them on the basis of lithologic variations and shifts in tempestite proximity. Sami and Desrochers' (1992) framework and their interpretation of depositional environments are followed herein.

Sami and Desrochers (1992) identified seven rock types through the whole sequence of the Becscie and Merrimack formations and arranged them into five distinct lithofacies (Fig. 2): calcareous mudstone-shale 1 (LF1), laminated-homogenous mudstone (LF2), calcareous grainstoneshale (LF3), laminated mudstone-grainstone (LF3) and laminated calcisiltite-grainstone (LF5).

The Becscie Formation spans the Ozarkodina hassi Zone in its lowest $13 \mathrm{~m}$ and the remainder lies within the Ozarkodina strena Zone (Zhang and Barnes, 2002a), and is of early to middle Rhuddanian age. The sampled section for interval
I is in the lower part of member 1 (Fox Point Member of Copper and Long, 1989) and in the lower part of the Oz. strena Zone, at 9-Mile Pool of the Rivière aux Saumons (section 1, Fig. 1). Twenty samples (p88-p107) were collected from this interval (Fig. 3). This section is dominated by light to dark gray non-laminated and laminated mudstones with minor amounts of nonlaminated and laminated wackestones and grainstones, which occur mostly as lenticular beds and channel troughs within the background mudstone units. Macrofossil fragments are common in the lenticular beds. This combination of rocks corresponds to LF2 of Sami and Desrochers (1992). These strata are interpreted to have been deposited near or below storm-wave base under lowenergy conditions; the coarser, lenticular beds indicate periodic tempestites that occurred at or above storm-wave base, in up to about $70 \mathrm{~m}$ water depth (Sami and Desrochers, 1992).

Within this interval, coniform species are ubiquitous. The most abundant species is Panderodus unicostatus (Branson and Mehl), and most samples contain 50 to $>100$ specimens of it, comprising $36-100 \%$, or $63 \%$ of the total fauna on average. The second most abundant species is Walliserodus curvatus (Branson and Branson), which numbers between 10 and 49 in most of samples, representing $9-28 \%$, or $16 \%$ on average.

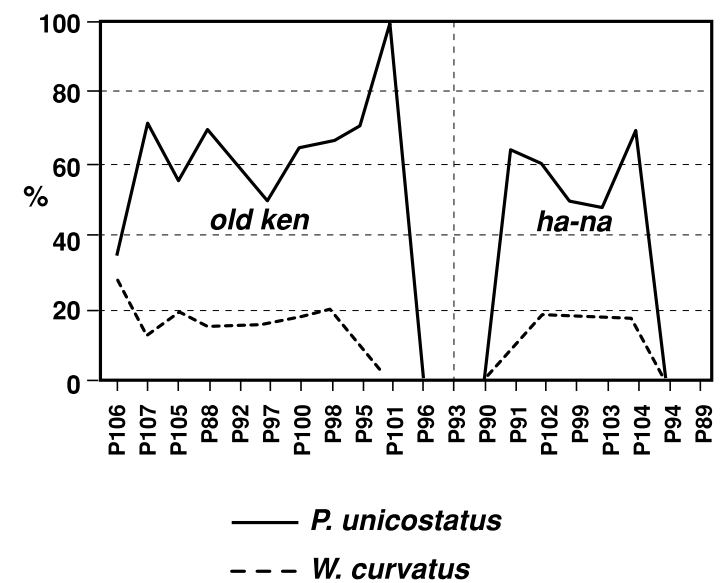

Fig. 4. The relative abundance (percentage of the total fauna) of Panderodus unicostatus and Walliserodus curvatus within the interval I section. Sample numbers from Fig. 3 are shown on the bottom axis. 


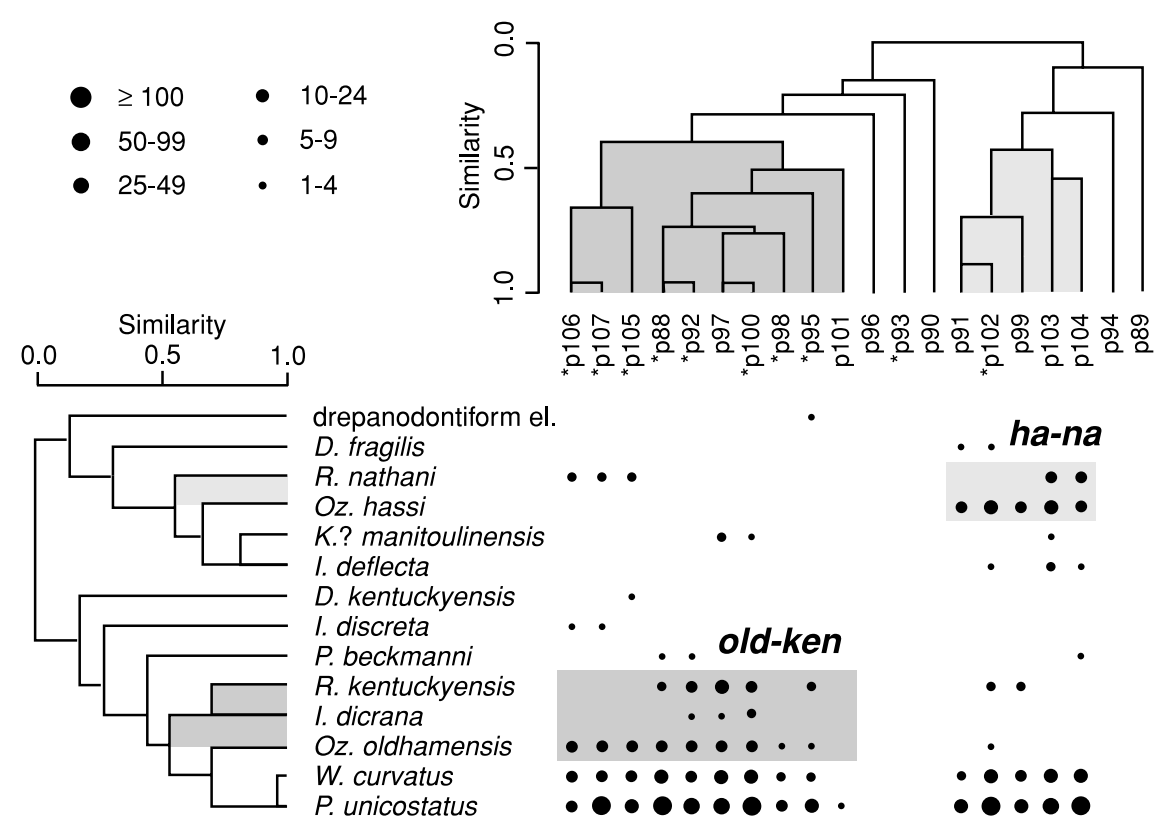

Fig. 5. Results of Q- and R-type cluster analysis of 20 samples from lower part of member 1, Becscie Formation, at 9-Mile Pool of the Rivière aux Saumons. Samples are in Q-type clustering order, taxa are in R-type cluster order and absolute abundances of taxa are expressed as a graded series of dots. Intersections of Q- and R-type clusters identify two communities (shaded), indicated by the abbreviations: old-ken, Ozarkodina oldhamensis-Rexroadus kentuckyenis; and ha-na, Ozarkodina hassi-Rexroadus nathani.

A relative abundance chart of $P$. unicostatus and $W$. curvatus as a percentage of the total fauna (Fig. 4) shows their antipathetic relationship, where an increase in one is usually marked by a decrease in the other. As both P. unicostatus and $W$. curvatus are almost ubiquitous and dominant species in most samples, the conodont communities were differentiated by other characteristic ramiform-pectiniform and ramiform species: Ozarkodina oldhamensis (Rexroad), Oz. hassi (Pollock, Rexroad and Nicoll), Rexroadus kentuckyensis (Branson and Branson) and $R$. nathani (McCracken and Barnes) (= Oulodus? kentuckyensis and $\mathrm{Ou}$.? nathani of McCracken and Barnes, 1981; Rexroadus was established by Zhang and Barnes, 2002a).

Cluster analysis of the fauna in these 20 samples identifies two distinct communities, the Ozarkodina oldhamensis-Rexroadus kentuckyensis community and the $O z$. hassi-R. nathani community (Fig. 5). Within the oldhamensis-kentuckyensis community, all samples produced 4-24 specimens of $O z$. oldhamensis, which amounts to $7-21 \%$, or $11 \%$ on average, of the total fauna; five samples yielded 5-27 specimens of $R$. kentuckyensis, which accounts for $5-16 \%$, or $8 \%$ on average. Within the hassi-nathani community, all samples contain 10-33 specimens of $\mathrm{Oz}$. hassi, which makes up $6-25 \%$, or $19 \%$ on average; all samples yielded 5-16 specimens of $R$. nathani, which amounts to $3-10 \%$, or $8 \%$ on average, of the total fauna. Besides these ubiquitous and characteristic species, the samples in the Q-type cluster analysis show that the oldhamensis-kentuckyensis and hassi-nathani communities have a further seven and six species, respectively, indicating that the species diversity of the two communities is similar.

The distribution of these two communities is strongly habitat-related, and almost completely restricted to the two different lithofacies. Nine samples contain the oldhamensis-kentuckyensis community, of which seven are from lenticular beds that represent the tempestites; and five samples yield the hassi-nathani community, of which four are from the non-laminated and laminated mudstones that represent the quiet depositional conditions. Thus, the oldhamensis-kentuckyensis community had a much narrower and more re- 
stricted habitat than the hassi-nathani community, with the former imported during times of major storms and their skeletal remains preserved mainly in narrow channel troughs and thin, lenticular, skeletal debris spreads. The question that then follows is whether the forms in the oldhamensis-kentuckyensis community were imported from a shallow or deeper water environment. Sami and Desrochers (1992) document that the tempestites flowed downslope in a north-west to south-east trend. However, the overall trend of eustasy in the Becscie Formation is an initial flooding event followed by an upward shallowing (Copper and Long, 1998; Jin and Copper, 1999). When the dominant occurrence of components of the dominant species in these communities is examined (see distributional data in Zhang and Barnes, 2002a,b), it is clear that Ozarkodina oldhamensis, for example, represents a deeper environment than does $O z$. hassi. As such, the elements of the oldhamensis-kentuckyensis community are interpreted as being imported from deeper shelf environments during storm surges and the skeletal remains concentrated and restricted to the channel fill deposits of the tempestites.

It is not unique that Ozarkodina oldhamensis and $O z$. hassi show a different environment preference on Anticosti Island, the samples from the Brassfield Formation of southern Ohio (Cooper, 1975) overwhelmingly produce $O z$. hassi, and only two samples bear $O z$. oldhamensis, which also lack $\mathrm{Pa}$ and $\mathrm{Pb}$ specimens of $\mathrm{Oz}$. hassi. This is likely controlled by lithofacies, although Cooper's (1975) work did not provide much information about the lithofacies.

The conodont paleoecology of the lower Becscie Formation was studied earlier using cluster analysis by McCracken and Barnes (1981). They also recognized two different communities, which are represented by Ozarkodina oldhamensis and $O z$. hassi, respectively. However, the conodont associations in the communities are different from the present result, i.e. Oz. oldhamensis and Rexroadus nathani are grouped together, and $\mathrm{Oz}$. hassi and R. kentuckyensis together. The main explanation for this difference in results is likely to be because they did not differentiate the $\mathrm{M}$ and $\mathrm{S}$ elements of $\mathrm{Oz}$. oldhamensis from those of $\mathrm{Oz}$. hassi, but attributed $\mathrm{M}$ and $\mathrm{S}$ elements of the two species arbitrarily to $\mathrm{Oz}$. hassi (McCracken and Barnes, 1981, p. 83 and in fig. 19), but to $\mathrm{Oz}$. sp. in both table 1 and element coding of $\mathrm{R}$-mode cluster analysis (McCracken and Barnes, 1981, p. 61 and p. 132). This caused both $O z$. oldhamensis and $O z$. hassi to be far less abundantly represented than in reality. Another possibility is that McCracken and Barnes (1981) compared Cooper's (1975) Oulodus sp. A and Oulodus sp. B in their synonymy to their Ou.? kentuckyensis, but Zhang and Barnes (2002a) placed Cooper's Oulodus sp. B in their synonymy of $\mathrm{Ou}$. $\mathrm{pa}$ nuarensis, which definitely affected the different number of specimens. Statistically, it is true that any changes to the database will bring different results.

\subsection{Interval II - Late Rhuddanian conodont communities}

The cliff section for interval II is within member 2 (Chabot Member of Copper and Long, 1989) of the upper Becscie Formation (late Rhuddanian), and $1 \mathrm{~km}$ north of 24-Mile Lodge, Rivière Jupiter (section 2, Fig. 1). Thirty-one samples were collected from this interval (Fig. 6). The proportions of lithologies from this section are quite different from those of interval $I$ in having a marked increase in lenticular beds that are dominated by non-laminated and laminated bio/intraclastic rudstones, wackestones and grainstones. The lenticular beds are commonly overlapping and cross-cutting, and some have a full range of tempestite rock types. Irregularly-bedded, laminated or cross-laminated mudstones form the background sedimentation and are poorly continuous laterally because of the channeling by the lenticular beds. This association belongs to LF4 of Sami and Desrochers (1992), and indicates deposition between storm-wave base and fairweather-wave base (Walker, 1985), and a low-energy ramp environment frequently affected by high-energy, erosive, storm currents. Water depths are interpreted as about $30-70 \mathrm{~m}$ using relationship to other lithofacies and brachiopod communities (Sami and Desrochers, 1992; Copper and Long, 1998); this is shallower than LF2 represented by interval I. 


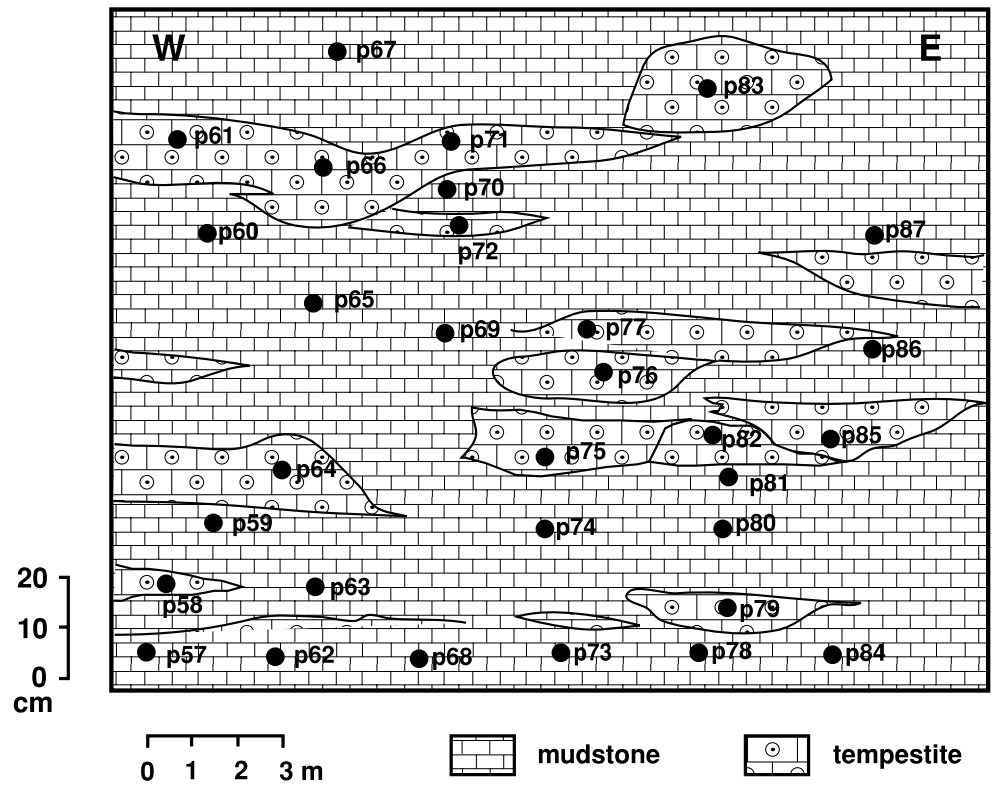

Fig. 6. Generalized sketch (view W-E) and sampling positions of interval II from member 2, upper Becscie Formation (late Rhuddanian), $1 \mathrm{~km}$ north of 24-Mile Lodge, Rivière Jupiter, Anticosti Island, Québec.

Within interval II, element abundance is much lower than for interval I and most species are represented only by one to four specimens except for Panderodus unicostatus. As for interval II, $P$. unicostatus is still a ubiquitous species, its relative abundance remains $50-100 \%$, or $65 \%$ on average, of the total fauna (Fig. 7). Its absolute abundance is less than that of interval I; most of the samples produced fewer than 50 specimens, with only one sample (p72) yielding over 100 specimens.

A less common species in interval II is Ozarkodina strena Zhang and Barnes, the zonal species for this stratigraphic interval. Its relative abundance varies widely from sample to sample, from $<5 \%$ to $100 \%$ ( $31 \%$ on average) (Fig. 7 ).

Both the relative and absolute abundances of Walliserodus curvatus between intervals I and II contrast strikingly. In interval II, $W$. curvatus is extremely rare, only three samples (p72, p77 and p84) bearing one or two specimens, compared to its ubiquitous occurrence in interval I. This indicates that $W$. curvatus preferred deeper water environments at or below storm-wave base. This preference for offshore settings was noted earlier by Aldridge and Mabillard (1981), McCracken (1991), and Jowett and Barnes (2000).
Cluster analysis of the 31 samples from interval II identifies three conodont communities (Fig. 8), which are less distinct than those in interval I. These are the Rexroadus kentuckyensis, the Panderodus unicostatus-Ozarkodina pirata, and the Ozarkodina strena communities. Within the kentuckyensis community, all samples produced 1-16

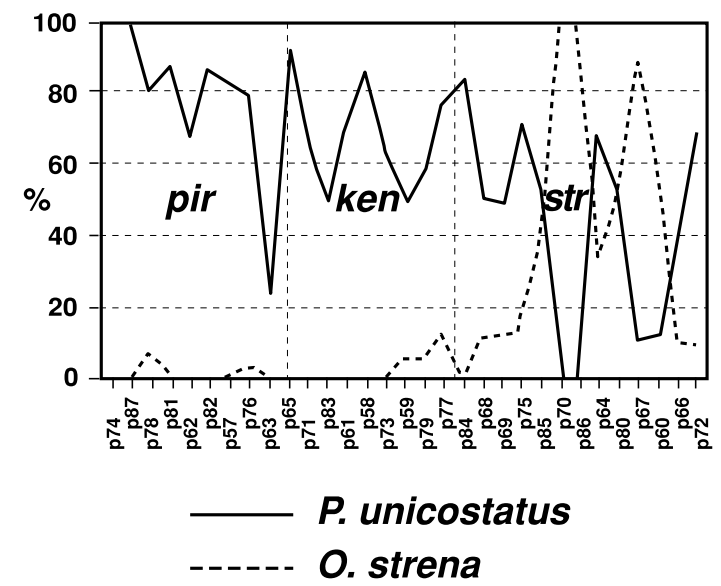

Fig. 7. The relative abundance (percentage of the total fauna) of Panderodus unicostatus and Ozarkodina strena through the interval II section. Sample numbers from Fig. 6 are shown on the bottom axis. 


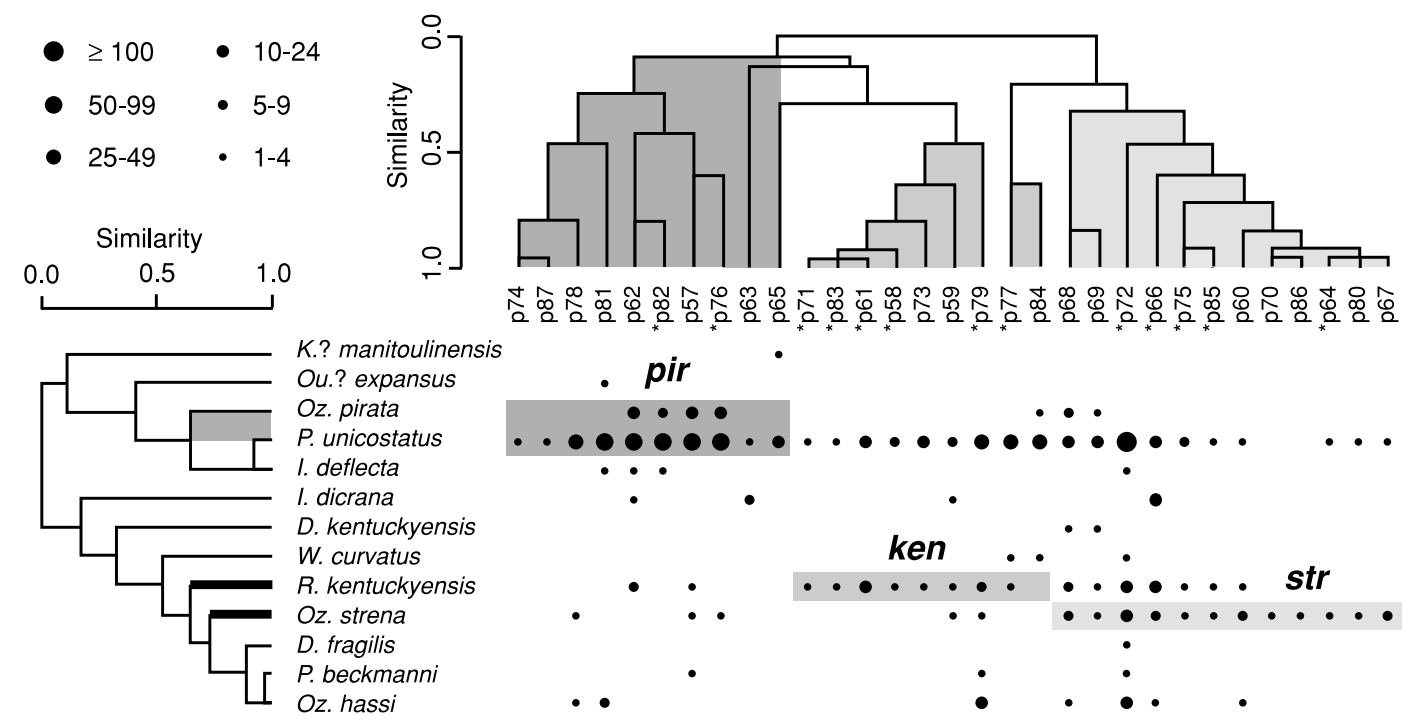

Fig. 8. Results of Q- and R-type cluster analysis of 31 samples of interval II from member 2, upper Becscie Formation, $1 \mathrm{~km}$ north of 24-Mile Lodge, Rivière Jupiter, Anticosti Island. Samples are in Q-type clustering order, taxa are in R-type cluster order and absolute abundances of taxa are expressed as a graded series of dots. Intersections of Q- and R-type clusters identify three communities (shaded) indicated by the abbreviations: pir, Panderodus unicostatus-Ozarkodina pirata; ken, Rexroadus kentuckyensis, and str, Ozarkodina strena.

specimens of $R$. kentuckyensis, which amounts to $4-33 \%$, or $19 \%$ on average, of the total fauna; within the unicostatus-pirata community, all samples contained 3-20 specimens of Oz. pirata, which makes up $10-19 \%$, or $14 \%$ on average. Within the strena community, all samples yielded 1-18 specimens of $O z$. strena, which accounts for $1-100 \%$, or $31 \%$ on average. Oz. strena and P. unicostatus exhibit an antipathetic relative distribution pattern (Fig. 7).

Among all three communities, only the kentuckyensis community shows a habitat preference. Of the seven samples grouped under the kentuckyensis community, five are from lenticular beds that represent tempestites. As in interval I, R. kentuckyensis may have been imported from deeper environments during storm surges that generated the channels and within which death assemblages were concentrated as the storm subsided, giving a different community from that found within the background mudstone sedimentation.

Although the kentuckyensis community can be recognized in this analysis, the cluster is not as tight as in the analysis for interval I, as the number of samples containing Rexroadus kentuckyen- sis which are not grouped together is greater than the number grouped together. In order to confirm the reliability of the results from the cluster analysis, a null hypothesis, stated as the independence between $R$. kentuckyensis and the lithofacies, has been constructed and tested. A simple chi-square test for a contingency table (Table 1) is applied to test for interaction between lithofacies (lenticular beds or non-lenticular beds) and presence or absence of $R$. kentuckyensis. The test in the $2 \times 2$ table reveals a significant value of the chi-square statistic $(\alpha=0.05)$ under which $\chi^{2}(5.796)>\chi_{0.05}^{2}$ (3.841). As the sample number for this test is less than 40 , it needs a small sample correction, producing $\chi^{2}(4.190)>\chi_{0.05}^{2}$ (3.841). The null hypothesis of independence between $R$. kentuckyensis and lithofacies is rejected.

The characteristic species of the two distinct communities of interval I, Ozarkodina oldhamensis and Rexroadus kentuckyensis, and $\mathrm{Oz}$. hassi and $R$. nathani, respectively, have relatively long stratigraphic ranges. Their first appearances occurred at almost the same time - in the earliest Rhuddanian, and their different last appearances are near the middle Aeronian as they extend into the over- 
lying Gun River Formation (Zhang and Barnes, 2002a). However, within interval II R. kentuckyensis is a characteristic species of a community, but $R$. nathani and $O z$. oldhamensis disappear locally, and $O z$. hassi is rare, occurring in just a few samples. This may suggest that $R$. kentuckyensis had a wider tolerance in respect of water depth and energy than the others.

Both the unicostatus-pirata and strena communities occur almost equally in the background mudstones that formed in a relatively low-energy environment as well as in the lenticular beds that represent relatively high-energy conditions. Such a distribution may suggest that: 1) during interval II deposition, between storm-wave base and fairweather-wave base, the high-energy storm currents might have caused more post-mortem mixing of conodont elements from the ramp and the channels, effected by the higher frequency of cross-cutting channels; or 2) Panderodus unicostatus, Ozarkodina pirata and Oz. strena may have had a wide environmental tolerance. The presence of the habitat-related kentuckyensis suggests that the second possibility is more likely, although some post-mortem transportation and mixing should probably not be excluded.

\subsection{Interval III - Early Aeronian conodont communities}

The Gun River Formation overlies the Becscie and Merrimack formations, and is of early to middle Aeronian age (Zhang and Barnes, 2002a). Five informal members were suggested for the formation by Petryk (1981a), which were assigned as the Lachute, Innommée, Sandtop and Macgilvray members by Copper and Long (1989). The Macgilvray Member includes part of members 3-5 of Petryk (1981a).

The cliff section of interval III occurs in the lower of middle part of member 3 (lower Sandtop Member of Copper and Long, 1998) of the Gun

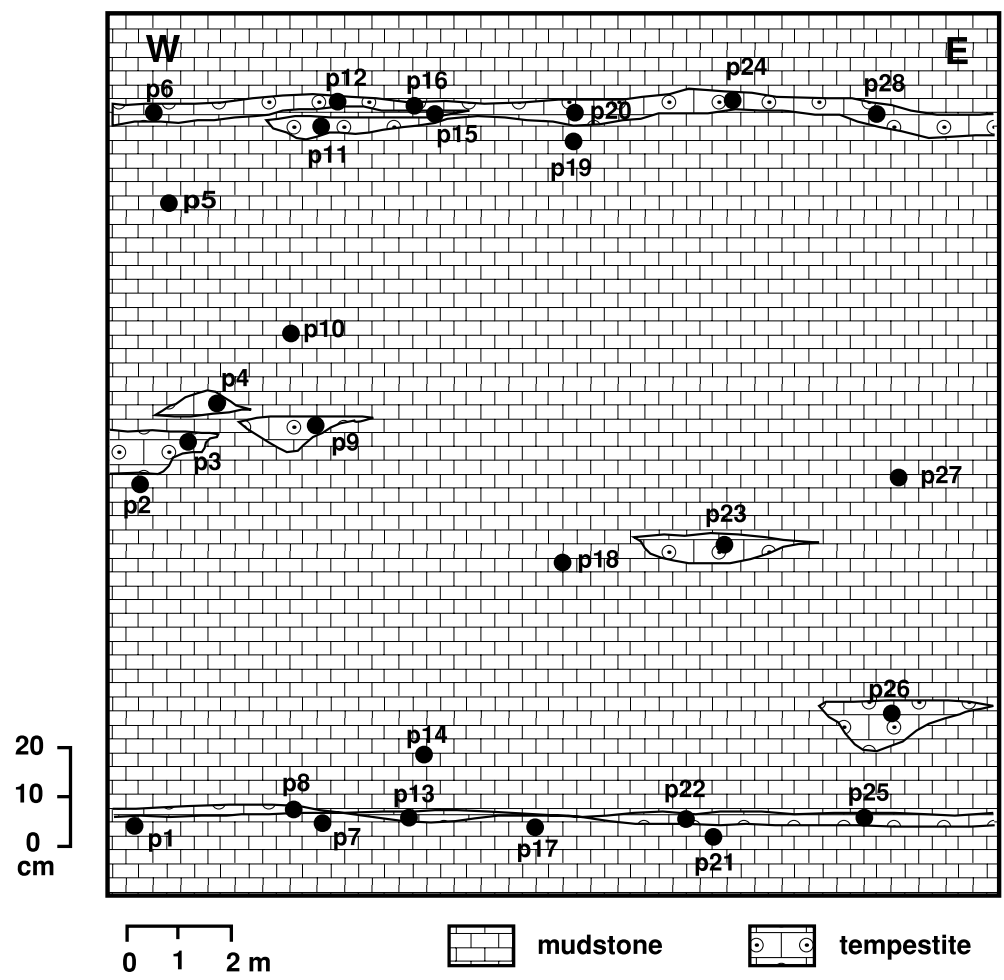

Fig. 9. Generalized sketch (view W-E) and sampling positions of interval III from member 3, Gun River Formation (early Aeronian), $2 \mathrm{~km}$ east of the mouth of the Rivière à La Loutre, south coast of Anticosti Island, Québec. 
River Formation, $2 \mathrm{~km}$ east of the mouth of the Rivière à La Loutre along the south coast (section 3, Fig. 1). The first appearance of Ozarkodina clavula Uyeno is taken as the base of the $O z$. clavula Zone by Zhang and Barnes (2002a). Interval III occurs in the lower part of this zone, which is dated as early Aeronian. Twenty-eight samples (p1-p28) were collected from this interval (Fig. 9).

The lithologies of interval III are similar to those of interval I, being dominated by mudstone with minor amounts of wackestone and grainstone, which occur mostly as lenticular patches and tabular thin beds between mudstone units. The bedding of the mudstones is continuous laterally except for the intersections of lenticular and tabular beds. This kind of association approximates to LF2 of Sami and Desrochers (1992), interpreted to have been deposited on a low-energy ramp at or just below the storm-wave base (deeper than $70 \mathrm{~m}$ ), but to have been disturbed periodically by high-energy currents above storm-wave base.

As with intervals I and II, Panderodus unicostatus is a ubiquitous species in interval III. Its relative abundance is higher than for the first two intervals, ranging between $50 \%$ and $100 \%$, or $82 \%$ on average. The second most abundant species is Ozarkodina pirata, whose number of specimens ranges from 10 to over 50 in most samples, and less than 10 in a few samples, accounting for $2-38 \%$, or $15 \%$ on average. A relative abundance chart of P. unicostatus and Oz. pirata (Fig. 10) shows their antipathetic relationship.

The cluster analysis identifies three distinct communities through interval III (Fig. 11). These can be recognized by the two ubiquitous species Panderodus unicostatus and Ozarkodina pirata, and the two characteristic species Ozarkodina clavula and Walliserodus curvatus. Among them, only $O z$. clavula does not appear in the other two communities.

The Ozarkodina clavula community has the highest species diversity among the three, the seven samples grouped under this community producing 12 species besides the characteristic species. Although $\mathrm{Oz}$. clavula has a very low absolute abundance, with each sample only containing one to four specimens, it shows a strong habitat correlation. All samples grouped under the clavula community are from the thick lenticular beds which represent tempestites. The Pa element of $O z$. clavula has a characteristic upper margin: slightly convex, bearing 13-15 evenly sized denticles that are free only at their tips. The characteristic species of the oldhamensis-kentuckyensis community of interval I, Oz. oldhamensis, has a similar $\mathrm{Pa}$ element to that of $\mathrm{Oz}$. clavula. Cladistic analysis reveals that $O z$. clavula shows common ancestry with $O z$. oldhamensis. Their stratigraphical ranges suggest that $O z$. oldhamensis may have given rise to $O z$. clavula, and this evolution appears to have occurred within a similar environment.

The Walliserodus curvatus community has a lower species diversity than the Ozarkodina clavula community, in which nine samples produce nine species. This community is obviously different from the clavula community in lacking $O z$. clavula. Although $W$. curvatus does appear in the clavula community, only three of seven samples yield one to four specimens, and it is a trivial component among the 12 species which are clustered together to form the clavula community. However, in the curvatus community, almost every sample produced specimens of $W$. curvatus, although it has low absolute abundance, with each sample containing one to four specimens of the characteristic species. In interval I, W. curvatus is a ubiquitous species both in high-energy and the low-energy environments, with relatively high

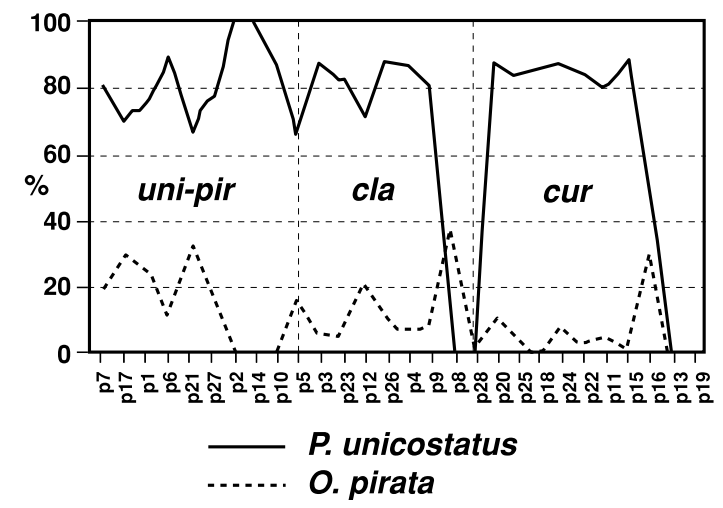

Fig. 10. The relative abundance (percentage of the total fauna) of Panderodus unicostatus and Ozarkodina pirata through interval III. Sample numbers are shown on the bottom axis. 

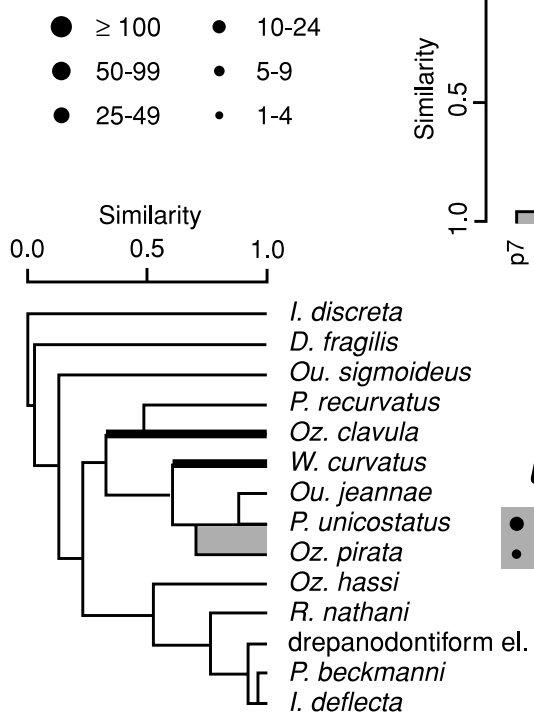
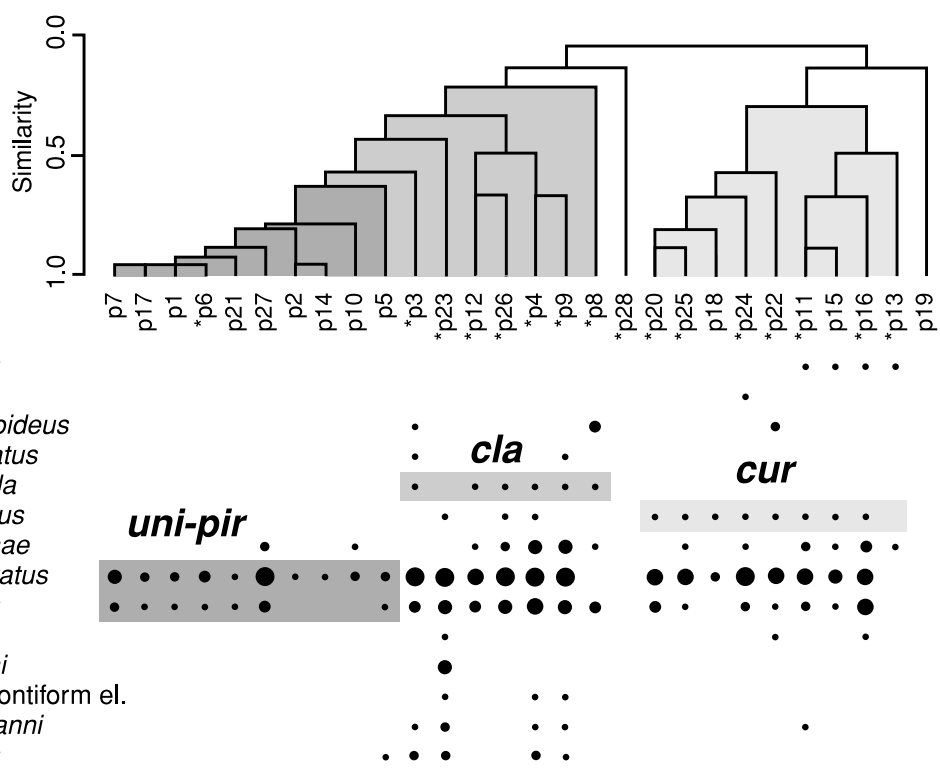

Fig. 11. Results of Q- and R-type cluster analysis of 28 samples of interval III from member 3, Gun River Formation, 2 km east of the mouth of the Rivière à La Loutre. Samples are in Q-type clustering order, taxa are in R-type cluster order and absolute abundances of taxa are expressed as a graded series of dots. Intersections of Q- and R-type clusters identify three communities (shaded) indicated by the abbreviations: uni-pir, Panderodus unicostatus-Ozarkodina pirata; cla, Ozarkodina clavula; and cur, Walliserodus curvatus.

absolute and relative abundance. However, in interval III, most specimens of $W$. curvatus are from thin lenticular beds, with a few specimens from the thick trough-lenticular beds, with only one exception in sample p18. Comparison of the occurrence of $W$. curvatus between interval I, II and III shows a different patterns of occurrence; it is a ubiquitous species in interval I, almost disappears in interval II, and only occurs in the thin lenticular beds in interval III. This probably indicates that $W$. curvatus preferred an environment below storm-wave base, but possibly with a narrower later habitat range.

As with interval II, in which the ubiquitous species Panderodus unicostatus and Ozarkodina pirata form their own cluster, interval III has two ubiquitous species that also combine into their own group, the $\mathrm{P}$. unicostatus $-\mathrm{Oz}$. pirata community. This has a characteristically low species diversity, with 10 samples from this community yielding only three species. Most samples have produced only $P$. unicostatus and $O z$. pirata with the exception of sample p27 and p10 which yield Oulodus jeannae Schönlaub, and most of the samples contain only one to nine specimens of the two species. All samples grouped in the $P$. unicostatus-Oz. pirata community are from the mudstones which were formed in the low-energy environment. Overall, the lithofacies of interval III indicate a ramp below storm-wave base (deeper than $70 \mathrm{~m}$ ), so the unicostatus-pirata community in interval III probably represents a deeper-water environment than that of interval II.

Fourteen species are found in interval III. Although none of the three communities identified from the cluster analysis includes all of them, the clavula community contains 11 species in addition to the characteristic species, namely Icriodella deflecta Aldridge, Oulodus jeannae, Ou. sigmoideus Zhang and Barnes, Ozarkodina hassi, $\mathrm{Oz}$. pirata, Panderodus recurvatus (Rhodes), P. unicostatus, Pseudooneotodus beckmanni (Bischoff and Sannemann), Rexroadus nathani, Walliserodus curvatus, and drepanodontiform elements. The curvatus community produces nine species, lacking $I$. deflecta and $R$. nathani and the drepanodontiform elements, but adding Decriconus fragilis (Branson and Mehl) and Icriodella discreta Pol- 
lock, Rexroad and Nicoll. The unicostatus-pirata community only produces $\mathrm{Ou}$. jeannae in addition to the ubiquitous species. The absolute abundance of Panderodus shows a decrease in the clavula, curvatus and unicostatus-pirata communities. Its specimen numbers range from over 100 specimens to $25-99$, then to $1-10$ in most samples of the three communities (Fig. 11).

If the more erosive, thick, trough-lenticular beds represented a higher-energy environment than the flat lenticular beds, then the species diversity from the three different communities in interval III may suggest that, below storm-wave base, (1) higher species diversity correlates with higher energy, (2) higher species diversity correlates with the higher absolute abundance of P. unicostatus, and (3) the low-energy subtidal ramp was the preferred habitat of relatively few conodont species.

\subsection{Interval IV - Early Telychian conodont communities}

The Jupiter Formation spans the Aeronian-Telychian boundary and Petryk (1981a) informally subdivided it into seven members. Uyeno and
Barnes (1983) combined his members 4-7 into a single member 4. Copper and Long (1990) subdivided the formation into the Goéland, East Point, Richardson, Cybèle, Ferrum and Pavillon members.

The Jupiter Formation is assigned to the middle and upper part of the Distomodus staurognathoides Zone of middle to late Aeronian through early Telychian age (Uyeno and Barnes, 1983). Interval IV lies within upper member 4 (Bolton, 1972) or the upper Pavillon Member (Copper and Long, 1990) at Jumpers on the south coast (section 4, Fig. 1), i.e. the uppermost part of the D. staurognathoides Zone (Uyeno and Barnes, 1983), or uppermost part of the Ozarkodina aldridgei Zone (Zhang and Barnes, 2002a). Twenty-eight samples (p29-p56) were collected from this interval (Fig. 12). Within interval IV, the association of lithologies is similar to that of interval II, and is comparable to LF4 of Sami and Desrochers (1992). The percentage of lenticular beds is greater than in interval II, and these beds tend to be more continuous laterally, with an increase in lenticular and wavy packstone and grainstone. This suggests that deposition occurred between storm-wave base and fairweather-wave

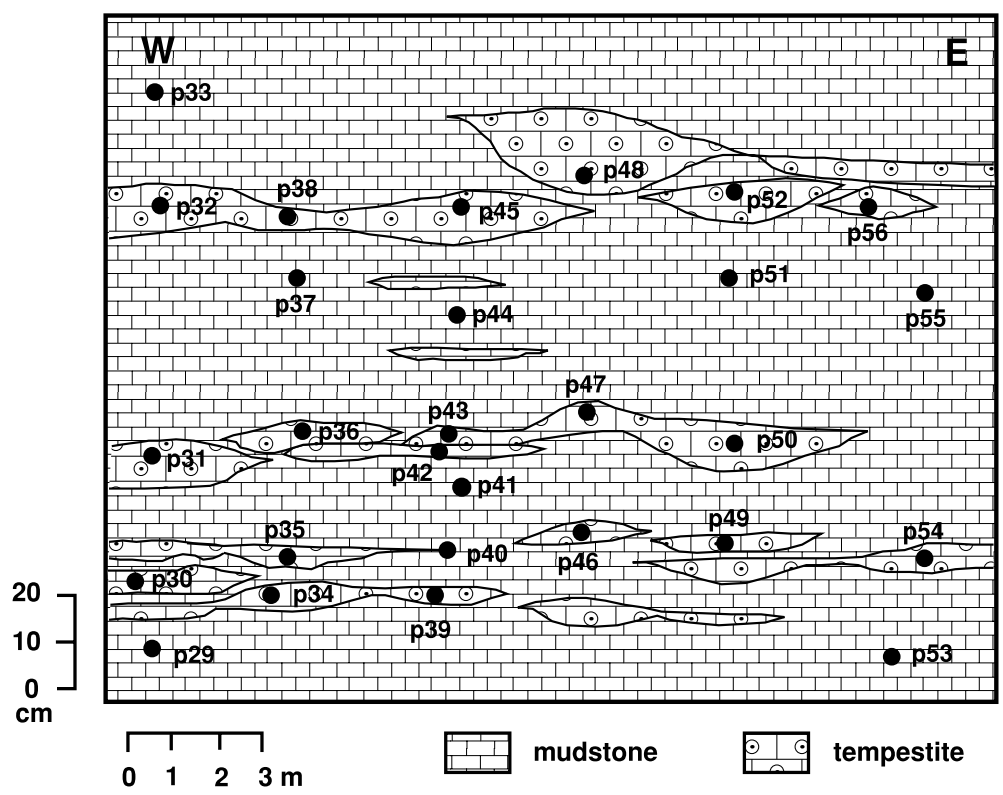

Fig. 12. Generalized sketch (view W-E) and sampling positions of interval IV from the upper member 4, Jupiter Formation, early Telychian, at Jumpers on the south coast of Anticosti Island, Québec. 


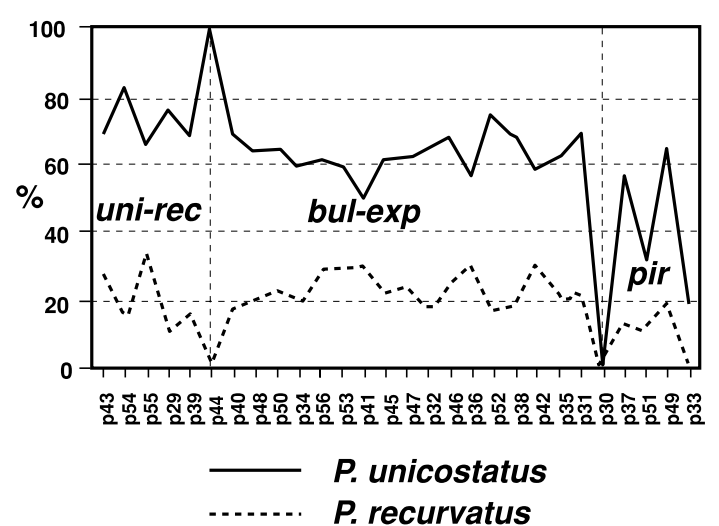

Fig. 13. The relative abundance (percentage of the total fauna) of Panderodus unicostatus and P. recurvatus through interval IV. Sample numbers are shown on the bottom axis.

base (Walker, 1985), with the low-energy ramp more repeatedly affected by high-energy, erosive, storm currents than for interval II. Copper and Long (1998) indicate water depths of about 30-70 $\mathrm{m}$ for the upper part of the Jupiter Formation as it shallows upward into the crinoidal shoal bank facies of the overlying Chicotte Formation.

As in the first three intervals, Panderodus unicostatus remains a ubiquitous species with both the highest relative and absolute abundance in interval IV. Fig. 14 shows that most samples contain over 25 specimens, and Fig. 13 shows that its relative abundance ranges between $50 \%$ and $100 \%$, or $63 \%$ on average. The second most abundant species is Panderodus recurvatus, with specimen yields ranging between 10 and 50, and less than 10 in a few samples, accounting for $11-33 \%$, or $20 \%$ on average. The relative abundance of $P$. unicostatus and $P$. recurvatus in this interval is shown in Fig. 13.

Cluster analysis identifies three distinct communities through interval IV (Fig. 14), among which the Aulacognathus bullatus-Oulodus? expansus community includes many more samples than the other two.

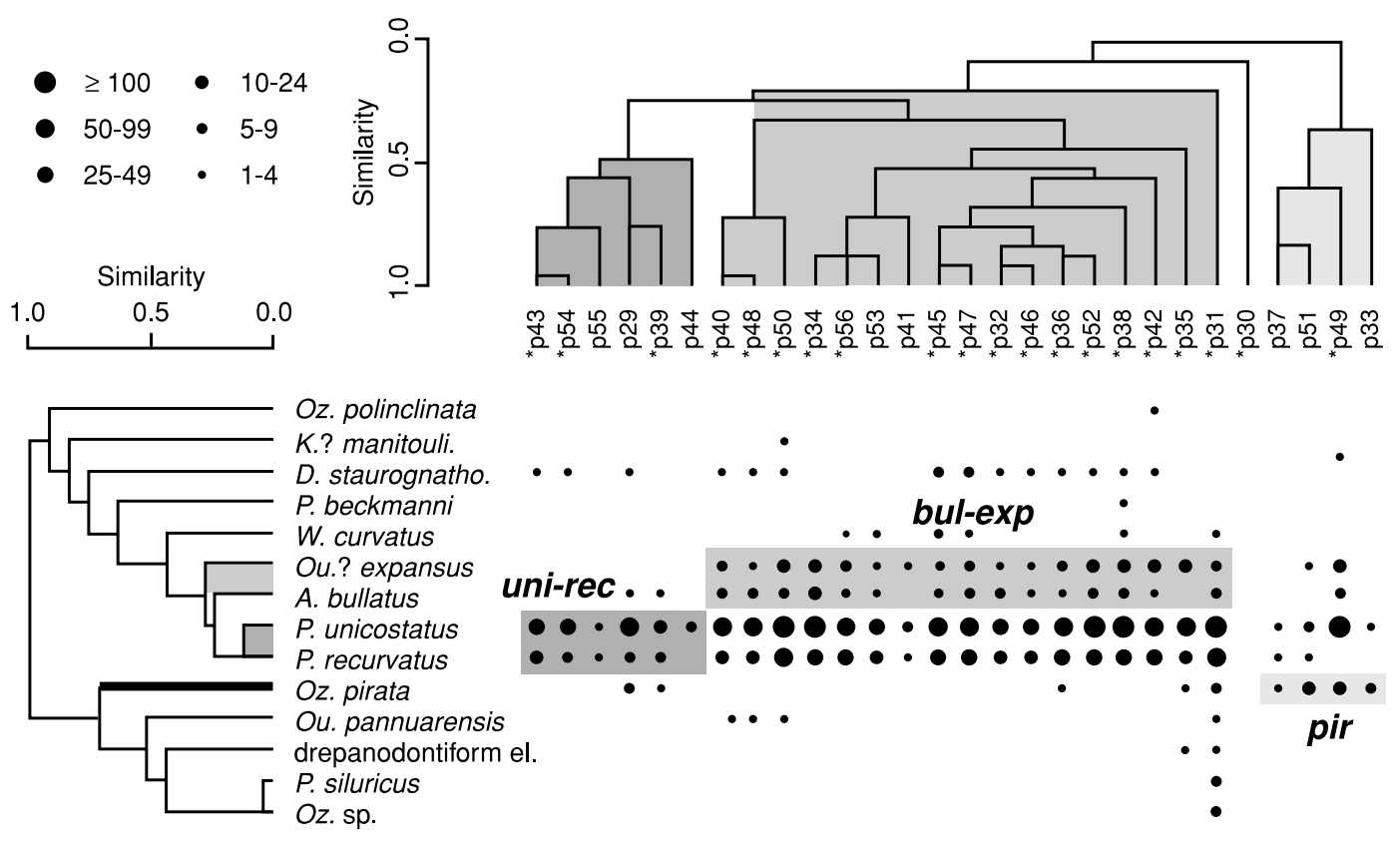

Fig. 14. Results of Q- and R-type cluster analysis of 28 samples from the upper member 4 of Jupiter Formation at Jumpers, south coast of Anticosti Island. Samples are in Q-type clustering order, taxa are in R-type cluster order and absolute abundances of taxa are expressed as a graded series of dots. Intersections of Q- and R-type clusters identify three communities (shaded) indicated by the abbreviations: bul-exp, Aulacognathus bullatus-Oulodus? expansus; pir, Ozarkodina pirata; and uni-rec, Panderodus unicostatus $-P$. recurvatus. 
This community is identified by a close cluster of Aulacognathus bullatus (Nicoll and Rexroad) and Oulodus? expansus (Armstrong). In this community, Panderodus unicostatus and $P$. recurvatus are the dominant species (Fig. 13), the relative abundance of $P$. unicostatus approximates $60 \%$, which is close to its average relative abundance for the interval $(63 \%)$, and that of $P$. recurvatus is $20 \%$, which is the same as its average relative abundance for the interval. The relative abundances of $P$. unicostatus and $P$. recurvatus (Fig. 13) exhibit an antipathetic relationship within this community. The absolute abundance of the two ubiquitous species in this community is higher than that in the other two communities (Fig. 14). The characteristic species of the community are A. bullatus and Ou.? expansus. The samples in Q-type clustering order among this community produce one to nine specimens of A. bullatus, which amounts to $1-8 \%$, or $4 \%$ on average, of the total fauna, and 1-24 specimens of Ou.? expansus which accounts for $2-11 \%$, or $7 \%$ on average, of the total fauna. This community shows a strong habitat preference, with 17 samples in Q-type clustering order among this community being from the lenticular tempestite beds with the exception of p40, p41 and p53. The lithology indicates that the bullatus-expansus community may have been deposited in an environment with high-energy storm currents between fairweather-wave base and storm-wave base, or more likely closer to fairweather-wave base. However, Ou.? expansus has been found elsewhere in deep-water, outer shelf and slope environments (Armstrong, 1990; Jowett and Barnes, 2000). Combining the possible conodont habitat and the depostional environment, it is possible that the bullatus-expansus community lived in a rela- tively deep environment, and was carried by storm surges towards the shoal banks.

Although there are only six samples with $\mathrm{Wal}$ liserodus curvatus among the 28 samples, all of them are grouped under the Aulacognathus bullatus-Oulodus? expansus community. In interval I, the presence of $W$. curvatus suggests that this species has a deeper water preference, and in interval III, it is closely related to the tempestites. Here, it is also related to the tempestites, which provides further evidence that the $\mathrm{A}$. bullatus-Ou.? expansus community was from deeper water imported by high energy surges.

Although in the R-type cluster, Distomodus staurognathoides (Walliser) does not show a very close relationship with Aulacognathus bullatus and Oulodus? expansus. Eleven out of 17 samples containing $D$. staurognathoides are closely grouped in the same Q-type clustering order with the bullatus-expansus community. However, three samples producing D. staurognathoides are clustered outside this community. Thus, a null hypothesis of the independence of $D$. staurognathoides and the lithofacies required testing, and a simple chisquare test for a contingency table (Table 2) has been used to investigate interaction between lithofacies (lenticular beds or non-lenticular beds) and the presence or absence of D. staurognathoides. The test of $2 \times 2$ table reveals non-significant values of the chi-square statistic $(\alpha=0.05)$ under which $\chi^{2}(1.152)<\chi_{0.05}^{2}(3.841)$, and $\chi^{2}$ $(0.459)<\chi_{0.05}^{2}(3.841)$ after a small sample correction. The null hypothesis of independence between D. staurognathoides and lithofacies is accepted.

Another small community can be recognized by the single species Ozarkodina pirata, which shows a distant relationship to the ubiquitous species in

Table 1

Contingency table with chi-square values for occurrence of Rexroadus kentuckyensis in lenticular beds and non-lenticular beds for interval II

\begin{tabular}{lccc}
\hline & Lenticular beds & Non-lenticular beds & Total \\
\hline Presence & 11 & 6 & 17 \\
Absence & 3 & 11 & 14 \\
Total & 14 & 17 & 31 \\
\hline
\end{tabular}

$\chi^{2}=5.796 ; \chi^{2}=4.19$ after small sample correction. 
Table 2

Contingency table with chi-square value for occurrence of Distomodus staurognathoides in lenticular beds and non-lenticular beds for interval IV

\begin{tabular}{lccc}
\hline & Lenticular beds & Non-lenticular beds & Total \\
\hline Presence & 11 & 4 & 15 \\
Absence & 7 & 6 & 13 \\
Total & 18 & 10 & 28 \\
\hline
\end{tabular}

$\chi^{2}=1.152 ; \chi^{2}=0.459$ after small sample correction.

R-type clustering order. The two ubiquitous species occuring in the four samples in Q-type clustering order of the community display an antipathetic relationship in their relative abundance (Fig. 13). Among the four samples, three occur in the non-lenticular mudstone, and one in the lenticular bed with grainstone. This suggests that the $O z$. pirata community had a habitat preference for the mudstone environment. However, there are another five samples which also produce $O z$. pirata, but are scattered outside this group, similar to Rexroadus kentuckyensis in interval II. Thus, another null hypothesis, stated as the independence of $\mathrm{Oz}$. pirata and the lithofacies, has been constructed and tested, and a simple chisquare test for contingency table (Table 3) applied to investigate any interaction between lithofacies (lenticular beds or non-lenticular beds) and the presence or absence of $\mathrm{Oz}$. pirata. The test of $2 \times 2$ table reveals non-significant values of the chi-square statistic $(\alpha=0.05)$ under which $\chi^{2}$ $(0.92)<\chi_{0.05}^{2} \quad(3.841), \quad$ and $\quad \chi^{2} \quad(0.277)<\chi_{0.05}^{2}$ (3.841) after a small sample correction. The null hypothesis of independence between $O z$. pirata and lithofacies is accepted. Thus, as in interval II, the unicostatus-pirata community may not have had a distinct habitat preference. This analysis supports statistically the contention that uni- costatus-pirata community of interval II and III represents two different water depths.

As in the analysis for interval III, the ubiquitous species are also combined into their own group, the unicostatus-recurvatus community, which is characterized by low species diversity, a wide difference in the absolute and relative abundance between the two species, and an antipathetic relative abundance. The samples in the Q-type clustering order of the community are equally scattered between lenticular beds and non-lenticular beds, which indicates that these species may not have had a strong habitat preference.

Fourteen species are found in interval IV. The three communities are identified by both ubiquitous and characteristic species. The samples in Q-type clustering order of the bullatus-expansus community contain all the species in this interval, but those in Q-type clustering order for the pirata and unicostatus-recurvatus communities incorporate only six and five species, respectively. Interval IV shows a decrease in the absolute abundance of Panderodus unicostatus from the bullatus-expansus community to the pirata community, and through to the unicostatus-recurvatus community. This further suggests that many conodonts symbolized higher energy environments: the higher the spe-

Table 3

Contingency table with chi-square values for occurrence of Ozarkodina pirata in lenticular beds and non-lenticular beds for interval IV

\begin{tabular}{lclr}
\hline & Lenticular beds & Non-lenticular beds & Total \\
\hline Presence & 5 & 4 & 9 \\
Absence & 14 & 5 & 19 \\
Total & 19 & 9 & 28 \\
\hline
\end{tabular}

$\chi^{2}=0.92 ; \chi^{2}=0.277$ after small sample correction. 

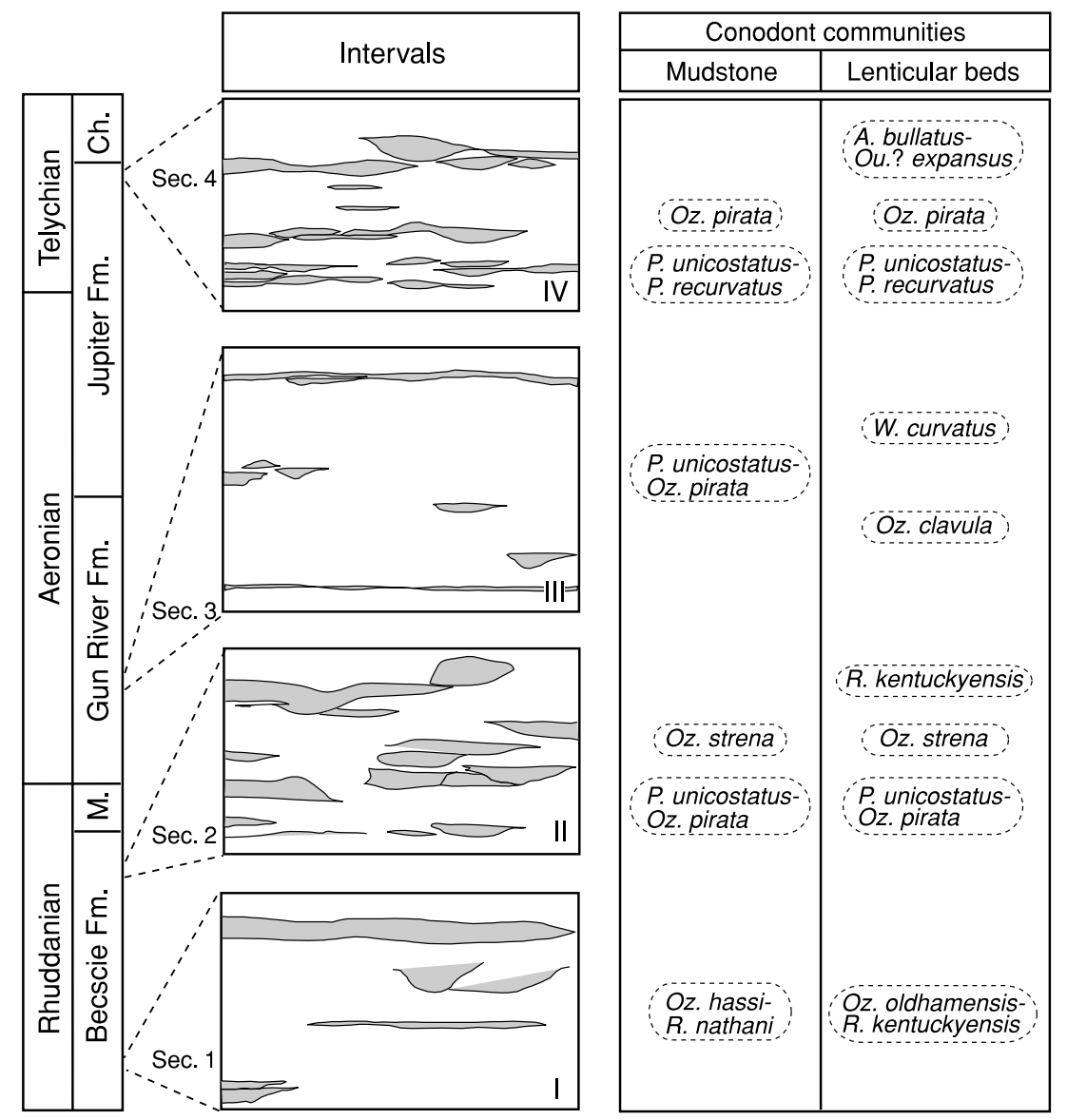

Fig. 15. The distribution of conodont communities through four Llandovery sections.

cies diversity, the higher the absolute abundance of $P$. unicostatus.

\section{Discussion}

Anticosti Island provides a relatively simple stratigraphy with a limited range of depositional settings with which to test models of Llandovery conodont paleoecology. The faunas are well preserved and the taxonomy has been recently completed to provide stable and consistent taxonomic identifications. The conodonts are present in sufficient abundance to apply statistical analyses to determine the pattern of communities, which have been outlined above. It has been shown that the
Llandovery Anticosti sequence was deposited on a gentle ramp in water depths of between 30 and 70 $\mathrm{m}$, rarely to $100 \mathrm{~m}$. Normal (background) sedimentation on the ramp was typically lime mudstone to wackestone, much of it deposited in quiet water environments at or below storm-wave base. The ramp was variably affected over time by storms that produced thin tabular to lenticular beds of coarse packstone, grainstone, or intrarudstone. These may be relatively widely spaced in some formations or concentrated and cross-cutting in others. A relatively simple two-component lithofacies grouping occurs in each of the four sections studied, which were sampled in considerable detail. The four stratigraphic sections in the lower and upper Becscie, lower Gun River and 
upper Jupiter formations provided a framework to analyze the changes in conodont communities through the Llandovery, to see the pattern of habitat preference by certain species, and to examine the possible mechanisms whereby certain species are restricted largely to the tempestite channel deposits (Fig. 15).

\subsection{Habitat distribution of simple cones}

The overwhelming component of the Llandovery conodont faunas on Anticosti Island is the coniform species Panderodus unicostatus. There have been many previous works dealing with Panderodus. Barnes and Fåhræus (1975) noted that Panderodus is dominant in littoral and subtidal facies of the Edenian of eastern North America. Aldridge (1972) suggested that the Llandovery simple cones were most abundant in offshore environments, and later (1976) he indicated that simple cone abundance correlates closely with water depth throughout the Silurian in the Welsh Borderland. Conodont faunas associated with deeper water benthic (brachiopod) communities consistently contained a high proportion of cones, particularly Panderodus. Aldridge (1976) also commented that coniform species distribution was controlled by a parameter that was significantly depth-dependent. In contrast, Aldridge and Mabillard (1981) suggested that Panderodus occurred commonly in shallow-water, near-shore environments. Idris (1984) reported that Panderodus from the Oslo Region disliked muddy environments, although it has commonly been recovered elsewhere from argillaceous samples. He also indicated that Panderodus had little affinity for shallow water, high-energy environments. Le Fèvre et al. (1976) suggested that the only widespread taxon of note in Hudson Bay Basin Silurian faunas that could be considered truly pelagic would be Panderodus.

The distribution of Panderodus unicostatus in the four intervals studied on Anticosti herein reveals that it is the only widespread and virtually ubiquitous taxon among all the species present, and it has both the highest relative and absolute abundance. This supports Le Fèvre et al.'s (1976) suggestion that $P$. unicostatus was truly pelagic.
The relative abundance of $P$. unicostatus has an antipathetic relationship with the relative abundance of most other species as documented above. The higher levels of absolute abundance of $P$. unicostatus are related to the high-energy tempestites.

The unicostatus-pirata community occurs in both intervals II and III, and is characterized by low species diversity and abundance. A water depth between storm-wave base and fairweatherwave base is inferred for interval II, and at or near storm-wave base for interval III, suggesting broad environmental tolerance of the community. Thus, the ubiquitous species, especially $P$. unicostatus, are considered to be eurytopic and probably pelagic.

Few detailed previous works have dealt with the paleoecology of Walliserodus curvatus. Idris' (1984, figs. 4 and 5) work on Silurian conodonts from Oslo Region suggests that $W$. curvatus had a preference for deeper waters and that it is most common in the furthest off-shore environment, also favored by the deeper water (brachiopod) Clorinda community (see Ziegler et al., 1968). The distribution of $W$. curvatus during the Llandovery on Anticosti Island partly supports this view. Indeed, it is most common at or below storm-wave base and widespread in both the channels and ramp during the earliest Rhuddanian (interval I), but this distribution pattern did not persist through the Llandovery. Its paucity during the late Rhuddanian (interval II) and early Telychian (interval IV) is likely due to these being shallower environments. Its restriction to the channels during the early Aeronian (interval III) may be related to its periodic importation from the deeper offshore shelf during times of storm surge.

\subsection{Habitat-related distribution of ramiform and ramiform-pectiniform conodonts}

Most ramiform and ramiform-pectiniform conodonts from the four sections show a habitat-related distribution. Near storm-wave base, Ozarkodina hassi and Rexroadus nathani are restricted mainly to the lime mudstone facies, whereas $O z$. oldhamensis, Oz. clavula and R. kentuckyensis are 
restricted to the high-energy channel deposits. In shallower facies that represent the zone between the storm-wave base and fairweather-wave base, $R$. kentuckyensis is much more common than $O z$. oldhamensis, while $O z$. hassi and $R$. nathani remain restricted to the high-energy channels; $A u$ locognathus bullatus and Oulodus? expansus are also related to the high-energy channels. A few species, such as $\mathrm{Oz}$. pirata, Ou. strena, and $\mathrm{Ou}$. jeannae do not show any significant habitat preference.

The Pa elements of both Ozarkodina oldhamensis and $\mathrm{Oz}$. clavula exhibit similar morphological characteristics and the evolutionary relationship of the two species may be one of ancestor-descendant. The distribution of both species shows a correlation with the high-energy channels near storm-wave base and is habitat-related, indicating a consistent ecological preference through time for this lineage.

\subsection{The relationship between species diversity and energy regime}

Except for interval II, most of the conodont communities defined by cluster analysis show a strong habitat correlation. Those related to the high-energy channels have higher species diversity. This is shown by the samples in Q-type clustering order that always contain more species than those related to the low-energy ramp and those not having any significant habitat preference.

\subsection{Post-mortem sorting}

Conodont elements have long been known to be susceptible to post-mortem sorting and breakage (Rhodes, 1952; Sweet and Bergström, 1962; Schopf, 1966; Webers, 1966; Kirchgasser, 1970; Collinson et al., 1972; Huddle, 1981). McGoff (1991) performed several flume experiments to understand the role of element sorting in determining death assemblage composition. Her results indicated that the samples that have undergone significant post-mortem sorting reflect only the hydrodynamic regime prevalent at the time of deposition and not the original faunal composition.
It is likely, acting as a heavy mineral, that conodont elements would normally be affected by some degree of lateral redistribution. Under strong and persistent current action, winnowing and preferential sorting and/or breakage may have occurred.

For the Anticosti lime mudstone samples, it is not envisaged, nor seen in the element distribution patterns, that there was significant redistribution of elements. In the tempestite spreads and channel fill deposits, some redistribution and preferential damage could be predicted. However, from the analysis of the distributional data there does not appear to be much of this, as opposed to the importation from deeper offshore environments of additional taxa. For example, the large specimens of Aulocognathus bullatus are associated with the smaller, delicate specimens of Oulodus? expansus [e.g. in the bullatus-expansus community of interval IV (Fig. 14)]. Although conodont specimens used for the paleoecology in this study are isolated elements from residues, most of the conodont communities defined by cluster analysis are habitat-related. If they were transported and mixed by any significantly post-mortem sorting, this consistent community distribution pattern would be obscured. Thus, the community distribution pattern from the four Llandovery sections (Fig. 15) suggests that the conodont elements did not undergo significant post-mortem sorting.

\section{Summary}

This study on the paleoecology of Llandovery conodonts from Anticosti Island, Québec, has built on the earlier and recent studies of the taxonomy and biostratigraphy of these faunas. Relatively little is understood of the correlation between conodont element and species distribution and detailed microfacies. The Anticosti sequence is dominantly of lime mudstones deposited on a gentle ramp in $30-100 \mathrm{~m}$ of water, at or near wave base. These mudstones are variably interbedded with, or cut by, tabular spreads and more lenticular channels of coarser packstone/ grainstone/intrarudstone interpreted as tempestites. Each of the studied sections has a generalized 
bimodal lithological association of mudstones and tempestites. Intervals I and III represent rather deeper ramp environments than intervals II and IV. The stratigraphic units sampled in four cliff sections, with a total of 107 conodont samples, are the lower and upper Becscie, lower Gun River and upper Jupiter formations. The samples yielded 9361 conodont elements, which were all identified and then subjected to cluster analysis that helped to define several conodont communities. The background sedimentation of the lime mudstone contains a different set of communities through time than those present in the tempestites. The latter do not simply yield conodonts that suggest they are re-sorted and concentrated from the storm-disturbed lime mudstones. Rather, they contain different taxa that, from studies of sequence stratigraphy and the eustatic changes in the Anticosti sequence, indicate that these new components were imported from more offshore environments during storm surges. The resulting communities found in the tempestites show the highest species diversity. These Llandovery conodont faunas reflect the initial evolutionary radiation following the terminal Ordovician mass extinction, induced by glaciation, and show distinct communities with strong habitat preferences.

\section{Acknowledgements}

C.R.B. gratefully acknowledges financial support for conodont research from the Natural Sciences and Engineering Research Council of Canada. S. Duffield measured the sections, collected the samples and undertook some initial study. S. Gardiner provided excellent field assistant support. Permission and support to undertake geological field work on Anticosti Island was given by Ministère des Richesses Naturelles, Québec, and the Ministère du Tourisme, de la Chasse et de la Pêche, Québec.

\section{References}

Aldridge, R.J., 1972. Llandovery conodonts from the Welsh Borderland. Bull. Br. Mus. (Nat. Hist.) Geol. 22, 125-231.
Aldridge, R.J., 1976. Comparison of macrofossil communities and conodont distribution in the British Silurian. In: Barnes, C.R. (Ed.), Conodont Paleoecology. The Geological Association of Canada Special Paper 15, pp. 92-104.

Aldridge, R.J., Jeppsson, L., 1984. Ecological specialists among Silurian conodonts. Palaeontology 32, 141-149.

Aldridge, R.J., Mabillard, J.E., 1981. Local variations in the distribution of Silurian conodonts: an example from the amorphognathoides interval of the Welsh Basin. In: Neale, J.W., Brasier, M.D. (Eds.), Microfossils from Recent and Fossil Shelf Seas. Ellis Horwood, Chichester, pp. 10-17.

Armstrong, H.A., 1990. Conodonts from the Upper Ordovician-Lower Silurian carbonate platform of north Greenland. Grønlands Geologiske Undersøgelse Bulletin 159, GGU, Copenhagen, pp. 1-151.

Barnes, C.R. (Ed.), 1976. Conodont Paleoecology. Geological Association of Canada Special Paper 15, pp. 1-324.

Barnes, C.R., 1988. Stratigraphy and paleontology of the Ordovician-Silurian boundary interval, Anticosti Island, Québec. In: Cocks, L.R.M., Rickards, R.B. (Eds.), A global Analysis of the Ordovician-Silurian Boundary. Bulletin of the British Museum (Natural History) Geology 43, pp. 195-219.

Barnes, C.R., 1989. Lower Silurian chronostratigraphy of Anticosti Island, Québec. In: Holland, C.H., Bassett, M.G. (Eds.), A Global Standard for the Silurian System. National Museum of Wales, Geolodical Series 9, pp. 101108.

Barnes, C.R., Bergström, S.M., 1988. Conodont biostratigraphy of the upper Ordovician and lowermost Silurian. In: Cocks, L.R.M., Rickards, R.B. (Eds.), A Global Analysis of the Ordovician-Silurian Boundary. Bulletin of the British Museum (Natural History) Geology 43, pp. 325-343.

Barnes, C.R., Fåhræus, L.E., 1975. Provinces, communities, and proposed nektobenthonic habit of Ordovician conodontophorids. Lethaia 8, 133-149.

Barnes, C.R., Petryk, A.A., Bolton, T.E., 1981. Anticosti Island, Québec. In: Lespérance, P.J. (Ed.), IUGS Subcommission on Silurian Stratigraphy (Ordovician-Silurian Boundary Working Group) Field Meeting. Anticosti-Gaspé, Québec, 1981, Vol. 1: Guidebook, pp. 1-24.

Barnes, C.R., Rexroad, C.R., Miller, J.F., 1973. Lower Paleozoic conodont provicialism. In: Rhodes, F.H.T. (Ed.), Conodont Paleozoology. Geological Society of America Special Paper 141, pp. 157-190.

Bolton, T.E., 1972. Geological map and notes on the Ordovician and Silurian litho- and biostratigraphy, Anticosti Island, Québec. Geologicla Survey of Canada Paper 71-19, pp. $1-45$.

Collinson, C.W., Avcin, M.J., Norby, R.D., Merrill, G.K., 1972. Pennsylvanian conodont assemblages from la Salle County, northern Illinois. Illinois Geological Survey Guidebook Series 10, pp. 1-3.7

Cooper, B.J., 1975. Multielement conodonts from the Brassfield Limestone (Silurian) of Southern Ohio. J. Paleontol. 49, 984-1008.

Copper, P., Long, D.G.F., 1989. Stratigraphic revisions for a 
key Ordovician/Silurian boundary section, Anticosti Island, Canada. Newslett. Stratigr. 21, 59-73.

Copper, P., Long, D.G.F., 1990. Stratigraphic revision of the Jupiter Formation, Anticosti Island, Canada: a major reference section above the Ordovician-Silurian boundary. Newslett. Stratigr. 23, 11-36.

Copper, P., Long, D.G.F., 1998. Sedimentology and paleontology of the Late Ordovician through Early Silurian shallow water carbonates and reefs of the Anticosti Island, Québec. Sedimentology and paleontology of the Early Ordovician through Early Silurian shallow water carbonates of the Mingan Islands National Park and Anticosti Island, Québec. Field Trip B8 Guidebook, Geol. Assoc. Can. (GAC), Min. Assoc. Can. (MAC), Assoc. des géologues et géophysicien du Québec (APGGQ), Int. Assoc. Hydrogeologists (IAH), Can. Geophys. Union (CGU) Joint Annual Meeting, 1998, Québec, pp. 55-94.

Dewing, K., 1999. Late Ordovician and Early Silurian strophomenid brachiopods of Anticosti Island, Québec, Canada. Palaeontogr. Can. 17, 1-143.

Druce, E.C., 1973. Upper Paleozoic and Triassic conodont distribution and the recognition of biofacies. In: Rhodes, F.H.T. (Ed.), Conodont Paleozoology. Geological Society of America Special Paper 141, pp. 191-273.

Huddle, J.W., 1981. Stratigraphy and conodonts of the Genesee Formation (Devonian) in Western and Central New York. US Geological Survey Professional Paper 1032-B, pp. 1-66.

Idris, M.B., 1984. Local variations in the distribution of Silurian conodonts of the Distomodus kentuckyensis Zone of the Oslo Region, Norway. Norsk Geol. Tidsskr. 64, 181-191.

Jin, J., Copper, P., 1999. The deep-water brachiopod Dicoelosia King, 1850, from the Early Silurian tropical carbonate shelf of Anticosti Island, eastern Canada. J. Paleontol. 73, 1042-1055.

Jowett, D.M.S., Barnes, C.R., 2000. Lower Silurian conodont biostratigraphy: integrating traditional paleontological data. GeoCanada 2000 Geoscience Summit, Abstract on conference CD.

Kirchgasser, W., 1970. Conodonts from near the Middle/ Upper Devonian boundary in north Cornwall. Paleontology 13, 335-354.

Klapper, G., Barrick, J.E., 1978. Conodont ecology; pelagic versus benthic. Lethaia 11, 15-23.

Le Fèvre, J., Barnes, C.R., Tixier, M., 1976. Paleoecology of Late Ordovician and Early Silurian conodontophorids, Hudson Bay Basin. In: Barnes, C.R. (Ed.), Conodont Paleoecology. Geological Association of Canada Special Paper 15, pp. 69-89.

Lespérence, P.J. (Ed.), 1981. IUGS Subcommission on Silurian Stratigraphy (Ordovician-Silurian Boundary Working Group) Field Meeting, Anticosti-Gaspé, Québec, 1981, Vol. 2: Stratigraphy and Paleontology, pp. 1-321.

McCracken, A.D., 1991. Taxonomy and biostratigraphy of Llandovery (Silurian) conodonts in the Canadian Cordillera, northen Yukon Territory. Geol. Surv. Can. Bull. 417, 65-95.

McCracken, A.D., Barnes, C.R., 1981. Conodont biostratigra- phy and paleoecology of the Ellis Bay Formation, Anticosti Island, Québec, with special reference to Late OrdovicianEarly Silurian chronostratigraphy and the systemic boundary. Geol. Surv. Can. Bull. 329, 51-134.

McGoff, H.J., 1991. The hydrodynamics of conodont elements. Lethaia 24, 235-247.

Nowlan, G.S., Barnes, C.R., 1981. Late Ordovician conodonts from the Vauréal Formation, Anticosti Island, Québec. Geol. Surv. Can. Bull. 329, 1-49.

Petryk, A.A., 1979a. Geology and hydrocarbon exploration of Upper Ordovician-Middle Silurian carbonate and clastic shelf facies, Anticosti Island, Québec. Geological Association of Canada and Mineralogical Association of Canada, Program with Abstract 4, p. 7.

Petryk, A.A., 1979b. Stratigraphie revisée de l'ile d'Anticosti. Ministère de l'Energie et des Ressources, DPV-711, pp. 124.

Petryk, A.A., 1980. Revised stratigraphy of Anticosti Island, Gulf of St. Lawrence, Québec. Geological Association of Canada and Mineralogical Association of Canada, Joint Annual Meeting, Program with Abstract 5, p. 75.

Petryk, A.A., 1981a. Stratigraphy, sedimentology and paleogeography of the Upper Ordovician-Lower Silurian of Anticosti Island, Québec. In: Lespérance, P.J. (Ed.), Subcommission on Silurian Stratigraphy, Ordovician-Silurian Boundary Working Group. Field Meeting, Anticosti-Gaspé, Québec 1981, Vol. 2: Stratigraphy and Paleontology, pp. 11-39.

Petryk, A.A., 1981b. Upper Ordovician glaciations: effects of eustatic fluctuations on the Anticosti platform succession, Québec. In: Lespérance, P.J. (Ed.), Subcommission on Silurian Stratigraphy, Ordovician-Silurian Boundary Working Group. Field Meeting, Anticosti-Gaspé, Québec 1981, Vol. 2: Stratigraphy and Paleontology, pp. 81-85.

Petryk, A.A., 1981c. Aulacerid ecostratigraphy and its bearing on the Ordovician-Silurian boundary on Anticosti Island, Québec. In: Lespérance, P.J. (Ed.), Subcommission on Silurian Stratigraphy, Ordovician-Silurian Boundary Working Group. Field Meeting, Anticosti-Gaspé, Québec 1981, Vol. 2: Stratigraphy and Paleontology, pp. 101-105.

Petryk, A.A., Bertrand, R., 1981. Géologie de la partie ouest de l'île d'Anticosti. Ministère de l'energie et des ressources, Québec, DPV-815, pp. 1-690.

Pohler, S.L., Barnes, C.R., 1990. Conceptual models in conodont paleoecology. Cour. Forsch.inst. Senckenb. 118, 409440.

Rhodes, F.H.T., 1952. A classification of Pennsylvanian conodont assemblages. J. Paleontol. 26, 886-901.

Sami, T., Desrochers, A., 1992. Episodic sedimentation on an early Silurian, storm-dominated carbonate ramp, Becscie and Merrimack formations, Anticosti Island, Canada. Sedimentology 39, 355-381.

Schopf, T.J.M., 1966. Conodonts of the Trenton group (Ordovician) in New York, southern Ontario and New York State Museum and Science Service Bulletin 405, pp. 1-105.

Scotese, C.R., 1997. Paleogeographic atlas. PALEOMAP Progress report 90-0497. PALEOMAP Project, University of Texas at Arlington. 
Scotese, C.R., Van Der Voo, R., Barrett, S.F., 1985. Silurian and Devonian base maps. In: Chaloner, W.G., Lawson, J.D. (Eds.), Evolution and Environment in the Late Silurian and Early Devonian. Philosophical Transactions of the Royal Society of London, B309, pp. 57-77.

Seddon, G., Sweet, W.C., 1971. An ecologic model for conodonts. J. Paleontol. 45, 869-880.

Sepkoski Jr., J.J., 1995. The Ordovician radiations: Diversification and extinction shown by global genus-level taxonomic data. In: Cooper, J.D., Droser, M.L., Finney, S.C. (Eds.), Ordovician Odyssey. Short Papers for the Seventh International Symposium on the Ordovician System. Pacific Section, SEMP Book 77, pp. 393-396.

SPSS, 1994. SPSS version 6.1 for the Macintosh. SPSS Inc., Chicago, IL.

Sweet, W.C., 1988. The Conodonta: Morphology, Taxonomy, Paleoecology, and Evolutionary History of a Long-Extinct Animal Phylum. Clarendon Press, Oxford.

Sweet, W.C., Bergström, S.M., 1962. Conodonts from the Pratt Ferry Formation (Middle Ordovician) of Alabama. J. Paleontol. 36, 1214-1252.

Sweet, W.C., Bergström, S.M., 1974. Provincialism exhibited by Ordovician conodont faunas. Soc. Econ. Paleontol. Mineral. Spec. Publ. 21, 189-202.

Sweet, W.C., Bergström, S.M., 1984. Conodont provinces and biofacies of the Late Ordovician. Geol. Soc. Am. Spec. Pap. 196, 69-87.

Uyeno, T.T., Barnes, C.R., 1983. Conodonts of the Jupiter and Chicotte formations (Lower Silurian), Anticosti Island, Québec. Geol. Surv. Can. Bull. 355, 1-49.

Varker, W.J., 1968. Conodont distribution in Yoredale Limestones $\left(D_{2}-E_{1}\right)$ of the North of England. Trans. Leeds Geol. Assoc. 7, 275-290.
Walker, R.G., 1985. Geological evidence for storm transportation and deposition on ancient shelves. In: Tillman, R.W., Swift, D.J.P., Walker, R.G. (Eds.), Shelf Sands and Sandstone Reservoirs. SEPM. Short Course Notes 13, pp. 243302.

Webers, G.F., 1966. The Middle and Upper Ordovician conodont faunas of Minnesota. Minnesota Geol. Surv. Spec. Pap. 4, 1-123.

Westrop, S.R., Cuggy, W.B., 1999. Comparative paleoecology of Cambrian trilobite extinctions. J. Paleontol. 73, 337-354.

Zhang, S., Barnes, C.R., 2000. Anticostiodus, a new multielement conodont genus from the Lower Silurian, Anticosti Island, Québec. J. Paleontol. 74, 662-669.

Zhang, S., Barnes, C.R., 2002a. A new Llandovery (Early Silurian) conodont biozonation and conodonts from the Becscie, Merrimack and Gun River formations, Anticosti Island, Québec. The Paleontological Society Memoir 57 (J. Paleontol. 76(2), Suppl.), 1-46.

Zhang, S., Barnes, C.R., 2002b. Late Ordovician-Early Silurian (Ashgillian-Llandovery) sea level curve derived from conodont community analysis, Anticosti Island, Québec. Palaeogeogr. Palaeoclimatol. Palaeoecol. X-ref: S00310182(01)00421-7.

Ziegler, A.M., Cocks, L.R.M., Bambach, R.K., 1968. The composition and structure of Lower Silurian marine communities. Lethaia 1, 1-27.

Ziegler, A.M., Hansen, K.S., Johnson, M.E., Kelly, M.A., Scotese, C.R., Van Der Voo, R., 1977. Silurian continental distributions, paleogeography, climatology, and biogeography. Tectonophysics $40,13-51$.

Ziegler, A.M., Scotese, C.R., McKerrow, W.S., Johnson, M.E., Bambach, R.K., 1979. Paleozoic paleogeography. Ann. Rev. Earth Planet. Sci. 7, 473-502. 